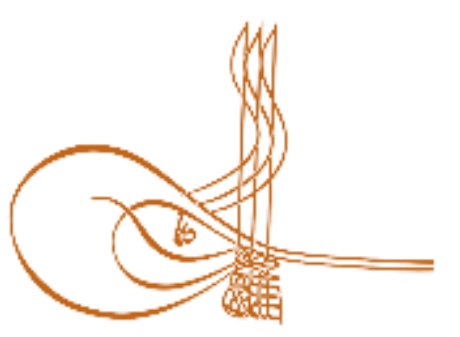

www.turkishstudies.net/turkishstudies
Turkish Studies

eISSN: $1308-2140$

Research Article / Araştırma Makalesi

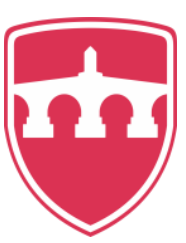

INTERNATIONAL

BALKAN

UNIVERSITY

Sponsored by IBU

\title{
Hukuk Bağlamında Bulgaristan'da Azınlıkların Hak ve Özgürlükleri
}

Rights and Freedoms of Minorities in Bulgaria in the Context of Law

\author{
Nargis Özgen*
}

\begin{abstract}
In 1989, the Turks living as citizens of this country in the face of policies and practices of the Bulgarian government, was forced to migrate to Turkey. That Sanctions such as changing names, banning religious worship, ending rituals such as circumcision and religious weddings, interfering with the wearing of shalwars, and prohibiting Turkish speaking and even Turkish music over time faced with resistance and penalties do not benefit caused the policy to be hardened and to death. The international legal dimensions of this migration process constitute the subject of this study. Turks living in Bulgaria still maintain the status of minorities in the Balkans, whose rights and freedoms were recognized at the earliest and those rights and freedoms were legally guaranteed. In spite of this, Turkish minorities were exposed to occasional intense political pressure in Bulgaria and were exposed to state assimilation policy in the 1980s. To guarantee the rights and freedoms of minorities in the national and international arena and to prevent their assimilation Bulgaria has signed many bilateral or multiple agreements in the legal arena and it has arouse a feeling that it has a protective attitude towards minorities in the international public. In this study, the legal aspects of the minority problem are tried to be explained in the context of bilateral or other multilateral agreements to protect Turks living in Bulgaria. It is possible to connect the very systematic implementation and management of its assimilation policy by Bulgaria to the regime in which it was ruled at that time. The structure of my political system on censorship and repression facilitates emigration, and does not allow foreign interventions by creating screens for the current administration. The legal agreements signed between the two countries in this process are insufficient to protect the rights and freedoms of Turks, who are minorities, in Bulgaria, it also serves for assimilation by causing loss of life and property in case of violations by the Bulgarian government.
\end{abstract}

Structured Abstract: When looking at the history of Turks in general, it is possible to observe a nonhomogeneous distribution in various parts of the world, which are caused by different reasons at different times. Turkish communities, which integrate with the communities they live in during these long periods of time, intertwine and ensure their existence over time, and also internalize their cultural structures into the societies in which they live, have managed to preserve their existence. Given the present day in which it has been sheltered in the legal framework, by perceiving the multicultural lifestyles are exalted, the identity differences between those who provide coexistence in a single society are more prominent and the

\footnotetext{
${ }^{*}$ Dr., TMF Genel Sekreteri

Dr., $T M F$

ORCID 0000-0003-4502-659X

nargisozgen@gmail.com

Cite as/ Atıf: Özgen, N. (2020). Hukuk bağlamında Bulgaristan'da azınlıkların hak ve özgürlükleri, Turkish Studies,

15(1), 535-563. https://dx.doi.org/10.29228/TurkishStudies.40336

Received/Geliş: 28 December/Aralık 2019

Accepted/Kabul: 25 February/Şubat 2020

Checked by plagiarism software

Copyright $\mathbb{C}$ MDE, Turkey 
metamorphosis as richness, the challenging conditions that Turks face in the adventure of existence, like many peoples or communities, can be overlooked. When viewed in terms of the perspective of individual, group, ethnicity, language, religion, lifestyle, nation and civilization perspective, struggle has been given to prevent assimilation and to preserve its current identity. When evaluated in terms of the Turkish society, which is stuck parallel to the West and East and serves as a bridge between both historical and cultural geographies, it is observed that there is a struggle for recognition. The examples of exposure Turkish communities, especially those who established themselves in Western societies, to be dissolved with various social and political practices in the societies in which they exist preserves its place in history. Turks, who are a minority in the land they live in, were exposed to assimilation and dissolution in the dominant culture with various government policies and practices. In recent history, with the examples in the late 1980s, discussion of migration to Turkey is important to get to the source of what happened. Turkey, witnessed individual migration from different countries, received the largest and most comprehensive mass migration from Bulgaria. Therefore, it appears before us that in the historical practice, the most worthy case is the case in the example of Bulgaria. Largest wave of immigration after the Second World War took place again in the direction of the Bulgaria-Turkey, which is the context of the main problematic of our study.

While in the study the mass displacement that took place from Bulgaria to Turkey since the proclamation of the Republic reveals the historical background, distant past of the subject, in our topic the migration, which took place in 1989, its causes and consequences are multifaceted, both countries called differently, and separated from other immigration, has very important dimensions. The most important of these are the political events that develop with immigration. The economic crisis in 1989, especially where relocation also contributed greatly, caused a political system change in Bulgaria, and the most severe effects of the collapse of the Eastern Block have been seen. A country, with minorities and struggles on the brink of civil war within the country, and having problems with the change of political regime in foreign policy, could not recover for a long time.

Minorities that have an important position in international relations and international law, in terms of Bulgaria, which has a large minority population especially the Muslim-Turkish minority in its country and wanted to be a member of Western international organizations and to integrate with the Western world after the collapse of the East Block in late 1989, have become a vital issue. The measures taken by the international community and Turkey against the assimilation policy of Bulgaria applied to the Turkish minority were inadequate and late, they did not have a deterrent role for Bulgaria. So, mosques closed by introducing sanctions such as starting with forced name change to assimilate the Turkish minority in the country of Bulgaria, prohibition of using Turkish, restriction of religious freedoms, preventing religious marriage and sunnah, imprisonment of those involved in these practices without going through the judicial process, even the banning of salwars worn by women by collecting religious books, and the social, economic and political rights of the Turks were taken away from their hand, and It followed an aggressive attitude towards goods, property and other material rights. Considering that the largest ethnic group living in Bulgaria is Turks and one tenth of the population, significance of the situation emerges.

To guarantee the rights and freedoms of minorities in the national and international arena and to prevent their assimilation Bulgaria has signed many bilateral or multiple agreements in the legal arena and it has arouse a feeling that it has a protective attitude towards minorities in the international public. However, when looking at the history, the immigration under the name of emigration, which occurs frequently and continuously, shows that the situation cannot be evaluated within the legal framework. It is not possible to put the assimilation and deportation policies by Bulgaria to the Turks living in their country into legal context. The pressure regime, which has no basis, seems very clear, and Bulgaria's agreements are violated in its favor.

It is possible to connect the very systematic implementation and management of its assimilation policy by Bulgaria to the regime in which it was ruled at that time. The structure of my political system on censorship and repression facilitates emigration, and does not allow foreign interventions by creating screens for the current administration. The legal agreements signed between the two countries in this process are insufficient to protect the rights and freedoms of Turks, who are minorities, in Bulgaria, it also serves for assimilation by causing loss of life and property in case of violations by the Bulgarian government.

Keywords: Minorities, Bulgaria, Migration, Assimilation, Relocation. 
Öz: 1989 yılında, Bulgaristan yönetiminin politika ve uygulamaları karşısında bu ülkenin vatandaşı olarak yaşayan Türkler, Türkiye'ye göç etmek zorunda kalmıştır. Ad değiştirme, dini ibadetlerin yerine getirilmesini yasaklama, sünnet ve dini nikah gibi ritüellere son verme, şalvarın giyilmesine müdahale etme ve zaman içinde Türkçe konuşulmasının hatta Türk müziğinin yasaklaması gibi yaptırımların direnişle karşılanması ve cezaların fayda etmemesi uygulanan politikanın sertleşmesine ve ölümlere sebep olmuştur. Yaşanan bu göç sürecinin uluslararası hukuki boyutları bu çalışmanın konusunu oluşturmaktadır. Bulgaristan'da yaşayan Türkler, Balkanlar'da hak ve özgürlükleri en erken tanınmış ve bu hak ve özgürlükleri hukuki güvence altına alınmış olan azınlıklar statüsünü halen korumaktadır. Buna rağmen Türk azınlıklar Bulgaristan'da dönem dönem yoğun siyasi baskılara maruz kalmış ve 1980 'lerde devlet eliyle yürütülen resmi asimilasyon politikasına tabi tutulmuşlardır. Ulusal ve uluslararası arenada azınlıkların hak ve özgürlüklerinin güvence altına alınması ve asimile olmalarının engellenmesi için hukuki arenada Bulgaristan ikili ya da çoklu pek çok anlaşmaya imza atmış ve uluslararası kamuoyunda azınlıklara karşı koruyucu bir tutum sergilediği izlenimini uyandırmıştır. Çalışmada; Bulgaristan'da yaşayan Türkleri korumaya yönelik ikili ya da diğer çok taraflı anlaşmalar bağlamında azınlık sorununun hukuki boyutları açıklanmaya çalışılmaktadır. Bulgaristan'ın asimilasyon politikasını çok sistematik olarak uygulaması ve yönetmesi o dönemde yönetildiği rejime bağlamak mümkündür. Siyasal sitemin sansür ve baskı üzerine konumlanmış yapısı tehciri kolaylaştırmakta ve mevcut yönetim için paravan oluşturarak dış müdahalelere izin vermemektedir. Bu süreç içerisinde iki ülke arasında imzalanan hukuki anlaşmalar azınlık durumundaki Türklerin Bulgaristan'da hak ve özgürlüklerini korumakta yetersiz kalmakta, Bulgaristan hükümetince ihlalleri durumunda da can ve mal kaybına neden olarak asimilasyona hizmet etmektedir.

Anahtar Kelimeler: Azınlıklar, Bulgaristan, Göç, Asimilasyon, Tehcir.

\section{Giriş}

Türklerin tarihine bakıldığında farklı zamanlarda farklı sebeplerden kaynaklanan, dünyanın çeşitli bölgelerinde homojen olmayan bir dağılımı gözlemek mümkündür. Söz edilen uzun zaman dilimlerinde yaşadıkları toplumlarla bütünleşen, iç içe geçen ve zaman içinde varoluşunun devamını sağlayan, kültürel yapılarını yerleşik oldukları toplumlara da içselleştiren Türk toplulukları varlığını korumayı başarmıştır. Çok kültürlü yaşam biçimlerinin yüceltildiği, tek toplum içerisinde birliktelik sağlayanlar arasındaki kimliksel farklılıkların daha çok ön plana çıktığı ve başkalaşımın zenginlik olarak algılanarak, hukuki çerçevede korunaklı hale getirildiği günümüz göz önünde bulundurulduğunda, birçok halk ya da topluluk gibi Türkler de varoluş serüveninde zorlayıcı koşullarla karşı karşıya kalmışlardır. Batı ile Doğu paralelinde sıkışmış olan ve her iki tarihin, kültürel yapısı arasında köprü vazifesi gören Türk toplulukları bir var oluş mücadelesi vermişlerdir. Özellikle Batı toplumları içinde kendilerine yaşam kurmuş Türk topluluklarının, var oldukları toplum içerisinde çeşitli politikalarla siyasi ve toplumsal baskıya maruz kalmışlardır.

Yakın tarihte, 1980'lerin sonunda yaşanan örnekle, Türkiye'ye göçlerin irdelenmesi yaşananların kaynağına gidilmesi açısından önemlidir. Farklı ülkelerden göçlere sahne olan Türkiye, kitlesel göçlerinden birini Bulgaristan'dan almıştır. 1989 tarihinde başlayan bu göçle, Mayıs 1990 tarihine kadar, Türkiye'ye 345.960 Türk göç etmiştir (Konukman, 1990: 71). Bu nedenle Türkiye'nin siyasi arenadaki konumunu etkileyen bu göçleri çeşitli açılardan irdelenmesi önem arz etmektedir.

Türkiye'de Cumhuriyetin ilan edildiği 1923 yılından itibaren Bulgaristan'da yaşayan Türkler üzerinde baskılar artmıştır (Konukman, 1990: 71). Son yüzyılın göç politikalarını ele alan kaynaklara bakıldığında Bulgaristan-Türkiye arasında yaşanan göçlerin, 1944 yılından itibaren mevcut siyasal rejiminin baskısı ile hız kazandığı tespiti ön plana çıkmakta ancak tarihi perspektifte Osmanlı döneminde de çeşitli toplu yer değiştirmelerinin mevcudiyeti bu tespitlerin çok da doğru olmadığını düşündürmektedir.

Çalışmada Cumhuriyet'in ilanından itibaren Bulgaristan'dan Türkiye'ye gerçekleşen toplu yer değiştirmeler konunun tarihsel arka planını, uzak geçmişini ortaya koyarken, konumuz 1989 
yılında gerçekleşen, neden ve sonuçları çok yönlü olan ve her iki ülkenin de farklı adlandırdı̆̆ 1 göçün diğer göçlerden ayrılan çok önemli boyutları vardır. Bunlardan en önemlisi göçle birlikte gelişen siyasal olaylardır. 1989 yılında özellikle tehcirin de büyük katkısının bulunduğu ekonomik bunalım Bulgaristan'da siyasal sistem değişikliğine neden olmuş, Doğu Blok'unun yıkılmasının en şiddetli etkileri görülmüştür. Ülke içinde azınlıklarla ve siyasi rejim değişikliğiyle sorun yaşayan ülke uzun süre toparlanamamıştır. Bu durumun etkileri, Türk azınlığa yönelik ağır yansımaları olmuştur. 1989 yılı öncesindeki göçlerde Türkiye'ye gelenler geçmişleriyle bağlarını koparmış, akraba ilişkilerini kesmiştir. Özellikle teknolojik alt yapı yetersizliğinin sonucu olan bu durum kökenlerin unutulmasına, zaman içinde yok olmasına sebep olmuştur. 1989 yılında Türkiye'ye yerleşenler açısından durum farklıdır. Serbest dolaşımın sağlanmasıyla birlikte Bulgaristan'dan gelen Türkler s1k sık Bulgaristan'a gitmeye ve geride kalan akrabalık ilişkilerini korumaya devam etmişlerdir. Bunun yanında Avrupa Birliği'ne giren Bulgaristan'ın çağrılarına duyarsız kalamayan Türk vatandaşı Bulgaristan göçmenleri, Bulgar vatandaşlıklarını yenileyerek çifte vatandaş konumuna geçmişlerdir. $\mathrm{Bu}$ durumun Bulgaristan yönetiminin yürüttüğü politikayla da ilişkilendirilmesinde fayda vardır. AB üyeliğine girme çabası içerisindeki ülke azınlık politikasında değişikliğe gitmiş, mevcut nüfusunu arttırma kaygısı ile doğru orantılı olarak Türkiye'de yaşayan Bulgaristan göçmenlerinin Bulgar kimliklerini alması için baskı uygulamıştır. Bu baskıların en canlı örneği olarak Bulgaristan'a gitmek için vize almak isteyenler için zor koşulların oluşturulması, vize fiyatlarının fahiş oranlarda yükseltilmesi, sınırdan Türk pasaportu ile geçiş yapmak isteyenlere çeşitli zorluklar çıkarılması gösterilebilir. Kısaca iki ülkede de varlığını sürdürmeye çalışan bir toplumdan söz etmek mümkündür.

1985 yılında Bulgaristan'da yaşayan Türklerin isimlerinin değiştirilmesiyle başlayan ve 1989 yılında Türkiye'ye tehcir ile sonuçlanan hükümet politikasının haklılı̆̆ının söylemsel ifadesi için, meşrulaştırılması ve azınlıklara uygulanan şiddetin geçerli gerekçeler biçiminde tutarlılaştırılması için bağımlı basın yayın organlarının öne çıkması kaçınılmazdır. Bu noktada organize bir propaganda ile karşılaşmak şaşırtıcı değildir. Olağanüstü hal dönemlerinde basın yayın organlarının bu gerekçelerle seferber edilmesi sık sık karşımıza çıkmaktadır. Fiziksel şiddetin yanında kullanılan ve sembolik şiddet olarak adlandırabileceğimiz bu durum propagandanın da dışına çıkarak sansüre kadar ulaşmıştır. Çalışmada propaganda modeli bağlamında yayınların sansüre ulaştığı noktalara değinilecektir ancak Chomsky’nin Amerikan Medyası için kullanmış olduğu "propaganda modeli"nin konumuz itibarıyla ihtiyacı gidermediği açıktır. Komünist rejimin idealize tanımlarının çok dışında olan baskılar totaliter rejimi işaret etmektedir ki, bu rejimlerin basın yayın organlarına uyguladıkları sansürler daha açık bir ifade ile "totaliter propaganda modeli" olarak açıklanabilir. Bu kavram totaliter rejimlerin politikalarından esinlenerek üretilmiştir. Bu modelin bir pratiğinin görülmesi açısından 1989 yılında gazetelerdeki haber ve yazılar analiz edilmiş ve mevcut söylemler ortaya konmuştur.

\section{Azınlık Kavramı}

Günümüz siyasal arenasında en büyük sorunlardan biri olan azınlık kavramı literatürde farklı tanımlarla yer almaktadır. Dünya genelini ilgilendiren böylesi önemli bir sorunun tanımı konusunda literatürde tam anlamıyla konsensüs sağlanamamıştır. Bunun nedeni kavramın dinamik bir yapıda olması ve çok boyutluluğu ile ilişkilendirilebilir. Kelime anlamı olarak Latincede küçük, az anlamına gelen azınlık kavramı, Türk Dil Kurumu tarafından üç ayrı şekilde tanımlanmaktadır². Bunlar;

1-Bir toplulukta kendine özgü nitelikler bakımından ayrı ve ötekilerden sayıca az olanlar, azlık, ekalliyet, çoğunluk karşııtı,

\footnotetext{
${ }^{1}$ Bulgar basını 1989 yılında gerçekleşen toplu yer değiştirmeyi “büyük gezinti” olarak adlandırırken, Türk basını "göç” olarak tanımlamaktadır. Çalışmada bu durum "tehcir" olarak isimlendirilecektir.

2 http://sozluk.gov.tr/ (Erişim: 04.08.2019)
} 


\section{2-Bir oylama sırasında sayıca az olma durumu ve}

3-Bir ülkede ayrı soydan veya inançtan olan ve sayıca az bulunan topluluk, ekalliyet şeklindedir.

Kurubaș azınlıkları "bir devletin nüfusunun geri kalanına göre sayısal olarak az olan, egemen konumda bulunmayan, -o devletin vatandaşı olan- üyeleri, nüfusun geri kalanından farklı etnik, dinsel ya da dilsel özelliklere sahip olan ve kültürlerini, geleneklerini, dinlerini ya da dillerini korumaya yönelik üstü örtülü de olsa bir dayanışma duygusu gösteren gruptur” (Kurubaş, 2004: 16), Türkdoğan ise azınlıkları "bir kültür içinde fizyonomi, dil, örf ve adetler veya kültürel örnekler açısından farklılaşma nedeniyle hâkim gruptan ayırt edilebilen alt gruplar" (Türkdoğan, 1999: 11) olarak tanımlamaktadır.

Akgönül'e göre azınlık/çoğunluk ilişkileri, her şeyden önce "ötekiliğin farkındalı̆̆ı" ve "başat olma ilkesi" üzerine kuruludur. Bu yüzden de "dini azınlık" kavramı "azınlık kavramının temelini oluşturur (Akgönül, 2016: 16). Akgönül, bir diğer azınlık tanımını ise uluslar üzerinden yapar. Ulus kavramını meydana getiren, aynı kökene sahip, aynı dili konuşan, aynı ahlaki ve düşünsel mirasa sahip olan, aynı yasalar altında yaşayan, aynı sevinçleri ve aynı acılara katlanan bireylerdir. Bu kriterlerden birini veya birkaçını barındırmayan topluluklara azınlık olarak bakılmaktadır. Yani azınlık kavramı negatif bir tanımdan ortaya çıkar. Başka bir deyişle, ulus için tanım yapılırken ulus olmayanlar içinde tanım yapılmakta ve ulus olmayanlar azınlık olarak adlandırılmaktadır. Azınlıklar bu durumda ulustan ayrı düşünülemez. Ulus olmayan yerde azınlıklardan bahsetmek mümkün değildir (Akgönül, 2016: 30).

Türkdoğan, azınlıkları "bir kültür içinde fizyonomi, dil, örf ve adetler veya kültürel örnekler açısından farklılaşma nedeniyle hâkim gruptan ayırt edilebilen alt gruplar" (Türkdoğan, 1999: 22) olarak tanımlarken azınlık kavramı içerinde üç ayrı kimlik ögesine vurgu yapmaktadır. Bunlar; kültürel, sosyal ve etnik kimlik ögeleridir.

Sosyal kimlik en yalın haliyle, kimliğin kişiler arası düzeydeki yansımasıdır. Tajfel'e göre sosyal kimlik; benliğimizin, belirli bir sosyal gruba ait olduğumuz hakkındaki bilgi veya bilincimize dayanan kısmıdır (Tajfel, 1981: 236). Sosyal kimlik, başka bir ifadeyle diğer insanlarla iletişim halindeyken kişilere atfedilen rollerin bütünüdür. Goffman ise sosyal kimliği, kişinin sosyal durumunu ön planda tutarak veya buna bağlı olarak gösterdiği davranışlar olarak açıklar (Goffman, 2009: 192).

Kültürel kimlikler çoğunlukla grup içerisindeki ilişkiler ve bu ilişkiler neticesinde kendiliğinden oluşan aidiyet duygusu ile meydana gelir. Larrain'e göre kültürel kimlik; tanımlanmış bir olgu, oluşmuş bir söz olarak, üretilen, sürekli üretim sürecinde olan, hiçbir zaman tümüyle tamamlanamayacak bir olgu olarak iki şekilde ifade edilir (Larrain, 1995: 217).

Etnik kimlik ise; dil, din, kültür, görünüş, soy ve bölgeselliğin harmonik bir bileşenidir. Etnik kimliğin mekânsal ve anlamsal sınırları hem etnik grup elemanları hem de üçüncü kişiler tarafından sürekli olarak dolayımlanır. Böylece kavram kendisini sürekli olarak yeniler.

\section{2- $\quad$ Bulgaristan'da Türk Azınlıklar}

Balkanlar'da Türk varlığı Hun Türklerine kadar uzanır, Orta Asya'dan göç eden çeşitli Türk boylarıyla devam eder. Bu topluluklar bölgenin kültürel gelişimine büyük katkıda bulunmuş ancak aynı çapta asimilasyona uğramışlardır. Örneğin Volga boylarında yasayan ve Türkçe konuşan Bulgar Türkleri, Slavların içinde asimile olmuş ve bir Slav topluluğu olarak anılmışlardır (Lütem, 2003: 146).

Türklerin Balkanlar'la olan ilişkisi Büyük Selçuklu ve Anadolu Selçuklu imparatorluğu dönemlerinde de devam etmiştir. Bölgede Müslüman toplulukların oluşumu da bu dönemde başlamış, özellikle II. Keykubat zamanında Bizans yönetimiyle iyi ilişkiler kurulmuş, Dobruca 
bölgesine Sarı Saltuklu Türkleri yerleştirilmiştir (Horata, 2003: 155). 13. yüzyılın sonlarında Anadolu Selçuklu Devleti'nin yıkılmasıyla Anadolu'da birçok beylik kurulur. Bunlardan biri olan Osmanlı Beyliği, kısa bir süre içinde Eskişehir, Bilecik, İnegöl ve Bursa'yı fethederek Osmanlı Devleti'ni kurar ve Anadolu'daki otorite boşluğunu doldurur (Sander, 2001: 59). On dördüncü yüzyılın ortalarından itibaren Süleyman Paşa komutasında Rumeli'ye geçen Türkler bu sayede Balkanlar'ı Fethe başlamışlardır.

$\mathrm{Bu}$ fetihler neticesinde, Osmanlı Devleti Bulgaristan'a 1389 yılında hâkim olmuştur (Halaçoğlu, 2002: 308). Farklı din, 1rk ve mezhebe mensup topluluklardan meydana gelen Osmanlı İmparatorluğu, siyasal, toplumsal ve yönetsel yapısı 1rk esasına değil inanç temeline göre şekillendirir (Küçük, 1986: 3) ve egemenliğindeki toplulukların, din ya da mezhep esasına göre örgütlenerek yönetilmesi "millet sistemi”" olarak adlandırılır (Eryılmaz, 1990: 17). Osmanlının dış politikasını oluşturan ana etmenlerden biri İmparatorluğa katılan topraklarda hoşgörü uygulamasıdır. Buna bağlı olarak egemenlik altına alınan Bulgar Halkının din, dil ve eğitim hürriyetine dokunmamış ancak Özbir'in de belirttiği üzere, Osmanlı İmparatorluğunun fetih politikası gereği fethedilen yerlere Anadolu'dan Müslüman-Türk Nüfus iskân ve aynı zamanda çeşitli imar faaliyetlerinde bulunarak, buraların Türkleşmesi hedeflenmiştir (Özbir, 1986: 86). Bu açıklamayla ek olarak belirtmek gerekir ki Osmanlı İmparatorluğu tarihinde herhangi bir azınlığa uygulanan asimilasyona rastlanmamaktadır.

Gelişen ve İmparatorluk şeklini alan Osmanlı istikrarlı bir genişleme göstermiştir. Osmanlı Devleti'nin gerçekleştirdiği bu büyük çaplı yayılmanın ardından, Öztürk'ün de ifadesiyle, Balkanlar'da büyük bir Müslüman-Türk nüfusu oluşmuştur. Sadece Müslüman ve Türk gruplar değil, hâkimiyet altında olan bütün Balkan ulusları, Osmanlı yönetimi altında parlak bir dönem geçirmişlerdir (Öztürk, 1999: 47-76). Ancak Fransız İhtilali ile birlikte, aşırı milliyetçilik akımlarının etkisi altına giren Balkan ulusları, Osmanlı yönetimine karsı, peş peşe bağımsızlık savası başlatmış ve kendi ulus devletlerini kurmuşlardır (Sander, 2001: 292).

Osmanlı Rus Savaşından ${ }^{3}$ yenik çıkan Osmanlı İmparatorluğu 3 Mart 1878'de Rusya ile Yeşilköy Antlaşması imzalanmıştır. Buna göre; Doğu Anadolu ve Rumeli'de büyük Osmanlı toprak kaybının yanı sıra Romanya, Sırbistan ve Karadağ'ın bağımsızlığı ve Tuna eyaletinde kurulacak geniş bir Bulgaristan Prensliği de kabul ediliyordu. Ancak Avrupa devletleri, Yeşilköy Antlaşmasını çıkarları ile doğru orantılı bulmamış ve 18 Haziran 1878'de Berlin Kongresinin toplanmasını sağlamışlardır. Bu kongrede alınan kararlara göre; Büyük Bulgaristan küçültülerek Balkan Dağları kuzeyinde oluşuyor, Korkut'un da ifadesiyle, savaştan önce nüfusunun yarıdan fazlası Türk olan bir Bulgaristan devleti kuruluyordu (Korkud, 1986: 6).

$\mathrm{Bu}$ gelişmeler Tuna eyalet topraklarında azınlıkta olan Bulgarlara bir ülke oluşturmuştur (Kekioğlu, 1985: 13). Berlin Anlaşmasıyla kurulan Balkan Dağlarının kuzeyindeki bir Bulgar Prensliği ve güneyinde de Doğu Rumeli Vilayeti (Oğuz, 1987: 59). Belirtmek gerekir ki,1877-1878 Osmanl1-Rus savaşı esnasında bir milyon bölge Türkü yurtlarından göçe zorlanmış ve bunlardan yarısı soykırımla katledilmiş, ağır tabiat şartları nedeniyle ölmüş ve azınlık konumu Bulgarlardan Türklere geçmiştir.

Türklerin ilk kez azınlık durumuna düştüğü Berlin Antlaşması'nda Türklerle ilgili olarak ilginç düzenlemelerin varlığı dikkati çeker. Bu anlaşmaya göre Türklere, burada azınlık yerine Türk ifadesinin kullanılması önemlidir, bu antlaşmayla Türklere istedikleri zaman anavatana taşınma tanınmıştır. 5. Maddeye göre, "Bulgaristan'da din ve mezhep ayrımı gözetilemez. Ayrı din ve mezhepten olan azınlıklar, tıpkı Bulgar çoğunluk gibi bütün medeni ve siyasal haklardan yararlanırlar. Bulgar Hükümeti, azınlıklara din ve ayin özgürlüğü tanımakla yükümlüdür”. Ancak mevcut durum bu değildir, Şimşir'in de belirttiği üzere Türklerin azınlık konumlarından faydalanan

\footnotetext{
${ }^{3}$ Rumi takvime göre 1293 tarihinde gerçekleşmesi nedeniyle 93 Harbi olarak da anılır.
} 
Bulgaristan anlaşmanın gereklerini yerine getirmemiştir. Ona göre, 1877-1886 yılları içinde Bulgaristan Türkleri hemen hemen bütün hoca ve öğretmenlerini kaybetmişlerdir, Türk azınlık okulları için öğretmen bulmak, yetiştirmek işi bundan sonra bir sorun olmuş, Türk mektep ve medrese binalarının önemli bir bölümü yakılıp yıkılmış ve bunların yerine yenilerini koymak zor olmuştur, Türklerin ekonomik üstünlükleri yok olmuş ve Türk halkı çok yoksul düşmüştür. Bu yüzden ayakta kalan Türk mektep ve medreselerini yaşatılıp geliştirmek Türk cemaati için büyük bir yük olmuştur. Türk vakıf malları geniş ölçüde yağma ve gasp edilmiştir. Yani Türk mektep ve medreselerinin gelir kaynağı daralmıştır (Şimşir, 1986: 30-32). Bu dönemde Türkler, “... Kendilerini ölümden ve kâlâ-yı' ismetlerinden (tertemiz namuslarının) telvis edilmesinden (kirletilmesinden) kurtarmak için, yirminci asır zalimleri tarafından dul ve yetim bırakılan kadınlar ve genç kızlar son hakaret olmak üzere, tebdîl-i din ettirilmek (din değiştirtilmek) felâketine mâr-uz kaldılar..." (Alp, 2008: 26).

Bununla birlikte üzerinde durulması gereken başka sorunlar da vardır. Lütem’e göre, savaştaki kayıpların yanı sıra, ekonomik ve kültürel bakımdan elit tabakanın Anadolu'ya göç etmesine, geriye fakir, savunmasız, haklarını aramakta yetersiz, kırsal kesimde yasayan bir toplum profili ortaya çıkarmış (Lütem, 2000: 59), bölge tarım arazilerinin \%70'ine sahip olan Türklerin azınlığa düşürülmesi ile ekonomik durumları da kötüleştirilmiştir (Şimşir, 1986: 20).

1908 y1lında Osmanlı İmparatorluğunda çıkan isyan ${ }^{4}$, devrimci hükümet iktidara getirir. Bu firsattan yararlanan Bulgaristan ve Avusturya-Macaristan harekete geçer. Habsburg imparatorluğunun Bosna-Hersek'i ilhak etmesiyle Ferdinand Bulgaristan'ın bağımsızlı̆̆ını ilan etmiş ${ }^{5}$, böylece Bulgaristan bağımsız Balkan devletleri safına katılmıştır (Jelavich, 2009: 41). 19 Nisan 1909'da Türk ve Bulgar hükümetlerince İstanbul'da imzalanan bir protokol ile Osmanlı Devleti'nin, Bulgaristan'ın bağımsızlığını tanıması sağlanmıştır. Toğrol'a göre bu protokol', Bulgaristan Türklerinin Bulgarlarla eşit haklara sahip olması ile birlikte özel azınlık haklarını, eğitim ve dini hürriyetlerini bir kez daha güvence ve teminat altına alıyordu (Toğrol, 1989: 18-70).

İki Balkan savaşı, Trakya'nın küçük bir kısmı ve İstanbul hariç, Osmanlı hakimiyetine son vermiş ve Jön Türk hareketi imparatorluğun gerilemesini durduramamıştır (Jelavich, 2009: 105). Osmanlının zayıf düşmesi ve bölgede hakimiyetinin son bulmasıyla Bulgarların Türklere karşı tavırları da değişme göstermiş, tam bir kayıp olarak adlandırılabilecek olan Balkan Savaşı sonrası Bulgarların bölgede yaşayan Türklere yönelik katliam ve soykırım hareketleri büyük ölçüde ivme kazanmıştır. Turan'a göre, bu dönemde Türk isimlerini değiştirme, Hıristiyan olmaya zorlama ve milli kıyafetlerini yasaklama ve camileri yakma gibi bazı uygulamalar olmuştur (Turan, 1995: 295). Buradaki önemli nokta isim değiştirme politikasının 1985 yılı politik yaklaşımın dışında da tarihsel süreç içerisinde kendisine yer bulduğudur. Alp'e göre, bu süreç geçmişten gelmektedir ve temellerinin atılması geçmişe dayanır. Ona göre, Bulgarlar homojen bir Bulgar- Slav topluluğu yaratma amaçlarını gerçekleştirmek maksadıyla 1910 yılında hazırladıkları bir plânla Pomak Türkleri $^{7}$ ile diğer Türkleri ayırmaya çalışmışlardır. Bulgarlar bu çerçevede, Müslüman Pomak Türklerinin yaşadığı köy, bucak, ilçe ve vilayetlerde Türkçe eğitimin yapılmasına izin vermemiş, Türkçe eğitimin yapılan okullara Pomak Türklerinin gitmesini yasaklamışlardır, Pomak Türklerinin folklorunu tahrip ederek, Bulgar folkloruyla birleştirmek istemişler, Ayet, hadis ve hutbeleri Bulgarca okumaya zorlamışlar, Anavatan "Türkiye sevgisi” yerine, "Anavatan Bulgaristan" sevgisini telkin ederek, ısrarla benimsetmeye çalışmışlar, Türk ve İslam düşmanlığının aşılanması için kreş, ilkokul, ortaokul ve bütün diğer okullara Bulgar asıllı öğretmenler tayin edilerek, Türkİslam düşmanlığını telkin edici temalar işlemişler, Türkleri, Bulgarların yaşadığı köy, kasaba ve şehirlere zorla iskân ettirerek, Bulgarların içinde eritmeye gayret etmişlerdir. Bu çalkantılı dönemde

\footnotetext{
${ }^{4}$ II. Meşrutiyet

5 Ekim 1908

${ }^{6}$ Adı geçen protokol İstanbul Protokolüdür.

${ }^{7}$ Bulgar kayıtlarında Pomaklar "Bulgar” olarak değerlendirilmektedir.
} 
genel tablo, kaynaklar farklılık göstermekte ve sayıları tam olarak bilinmemekle birlikte, Ağanoğlu, 1.230.000 ile 1.253.000 kadar Türk Türkiye’ye göç ettiğini belirtmektedir (Ağanoğlu, 2001: 33).

Osmanlı hakimiyetinin son bulduğu bir dönemden söz ederken ilginç bir ayrıntıya yer vermek gerekir. Uzun bir süre Balkanlar'da üstünlük sağlayan bir imparatorluğun Balkanlar üzerinde etki bırakması kaçınılmazdır. Jelavich'e göre, bir Balkan devleti ne kadar milliyetçi olmak isterse istesin, Osmanlı idaresinin mirası, her bireyin hayatının ayrılmaz ve kolayca silinmeyecek bir parçasıydı. Örneğin bütün ulusların dillerine pek çok Türkçe kelime girmiştir. Bunun yanında Osmanlı mimarisinin güzel örnekleri de Balkanların her alanına yayılmıştır (Jelavich, 2009: 109110). Bununla birlikte elbette ki olumsuz veçhelere de rastlanmaktadır.

Osmanlı mirasının hem olumlu hem de olumsuz veçheleri, ilerleyen yıllarda bütün devletlerin tarihine yansıyacaktı. Ortak bir kültürü paylaşmaları Arnavutluk, Bulgaristan, Yunanistan, Romanya ve savaştan sonra Türkiye ile Yugoslavya arasındaki en önemli bağ olacaktı (Jelavich, 2009: 110). Bu ayrıntının ve Vucinich'in olumsuz tespitlerinin aktarılmasının çalışmamız açısından ortak kültürel değerlere vurgu yapmaktır. Her ne kadar farklı kültürlerin çatışması çalışmamızın odağını oluştursa da temelde iki kültür de birbirinden etkilenerek şekillenmiş ve bugüne taşınmıştır. Bu açıklamalar ışığında söz konusu baskı ve asimilasyon politikalarını anlamak zorlaşmaktadır.

Birinci Dünya savaşında aynı ittifakta yer alan ve yenilen Osmanlı İmparatorluğu ve Bulgaristan'da savaş sonrası önemli gelişmeler görülmektedir. Osmanlı İmparatorluğu 30 Ekim'de teslim olur. Böylece savaş aralarında Balkan devletlerinden Romanya, Sırbistan ve Yunanistan'ın da bulunduğu İtilaf Devletleri'nin mutlak zaferiyle sonuçlanır. Bulgaristan ve Osmanlı İmparatorluğu mağluplar arasındadır (Jelavich, 2009: 129). Bu büyük yenilginin yanında Kekioğlu'na göre, Osmanlı İmparatorluğu'nda Milli Mücadelenin başladığı sırada Bulgaristan'da, önce ihtilal ve arkasından seçimle Çiftçi Partisi yönetime gelmiştir. Bu parti yönetimi altında Bulgaristan Türkleri ilk kez rahat bir nefes almış ve 1918-1923 yıllarını kapsayan bu dönemde en huzurlu günlerini geçirmişlerdir (Kekioğlu, 1985: 19). Bu durumun önemli sebeplerinden biri de Osmanlı İmparatorluğu'nun sonunu getiren ve Türkiye Cumhuriyeti'nin kuruluşu ile sonuçlanan "Kurtuluş Savaşı" mücadelesi olarak gösterilebilir. Bu dönemde de Türk Bulgar ilişkileri hız kesmeden devam etmiştir. Bulgaristan'ın kurucuları arasında gösterilen Georgiy Dimitrov'un, Türkiye Kurtuluş Savası ile ilgili olarak, "Büyük kan pahasına ellerine silahlarını alıp ülkelerinden emperyalist istilacıları kovmayı başaran ve milli bağımsızlıklarını kazanan Türk milleti büyük bir gurur duymakta haklıdır" ifadesini kullanması ilgi çekicidir (Velikov, 1996: 7). Türk Kurtuluş Savaşını en açık şekilde destekleyen yayın organı olan Rabotniçeski Vestnik, 08.09.1922 tarihli baskısında "Tükler Anadolu'da sadece Yunan ordusunu mağlup etmediler. Yunan ordusunun Türkler tarafindan mağlup edilmesi İngiltere'nin de mağlubiyetidir. Türklerin bu büyük zaferi İngilizlerin emperyalist siyasetlerini mağlup etmiştir.” açıklamasına yer verir. Bu dönemde Bulgaristan her anlamda Türkiye'deki mücadelenin yanında ve arkasında bir tavır benimser. Bu durulmaya bir başka neden olarak Aleksandır Stamboliyski (1919-1923) dönemi boyunca Bulgaristan'ın yayılmacı politikalarından vazgeçerek Balkan Savaşları ile başlayıp Birinci Dünya Savası ile devam eden milli felaket dönemlerinin yaralarını sarmaya çalışması gösterilebilir. Birinci Dünya Savası sonrasında Bulgaristan dış politikasına, Aleksandır Stamboliyski'nin dünya görüsü ve ülkenin içinde bulunduğu durum yön vermiştir. Stamboliyski iktidarının dış politika ile ilgili temel prensibi, hayatın her alanında olduğu gibi, tam bağımsızlık ve bağımsız bir dış siyaset takip etmektir. Stamboliyski, "Ben ne Rusofilim, ne de Germanofil... Ben sadece Bulgarofilim ve ancak Bulgarofil olabilirim" açıklamasını çekinmeden yapmıştır (Stamboliyski, 1979: 225). Bu açıklamadan da anlaşılabileceği üzere Stamboliyski'nin görüşleri bundan önceki dönemlerin aksine Bulgaristan diş siyasetinde Alman ve Rus izlerinin görünmeyeceği anlamı taşımaktadır. Jelavich'e göre, Stanboliyski'nin iktidarda olduğu dönem boyunca toprak reformu, çalışma mükellefiyetinin getirilmesi ve köy düzeyinde eğitimin iyileştirilmesini kapsayan önemli kanunları çıkarmayı başarmış, Bulgaristan o 
dönemde Balkanlardaki en eşitlikçi toprak sistemine sahip olduğundan, hiçbir radikal kanuna ya da istimlake gerek duyulmamış, bununla birlikte hükümet, devletin, manastırların ve köy idarelerinin elindeki mülkler de dahil olmak üzere, elde edebildiği bütün arazileri dağıtmıştır (Jelavich, 2009: 178). Ancak belirtmek gerekir ki Bulgaristan'dan Türkiye'ye göçler Cumhuriyet döneminde de hız kesmeden devam etmiş, Cumhuriyetin kurulmasını izleyen yıllarda Anadolu'ya ikinci büyük göç dalgası Bulgaristan'dan gelmiştir. Bulgaristan'dan gerçekleşen göçler aralıklarla 1989 yılına kadar sürmüştür.

Birinci Dünya Savaşı sonunda Bulgaristan'ın imzaladığı Neuilly Antlaşması, Bulgaristan Türk azınlığının dini, kültürel ve eğitim alanındaki haklarını teminat altına alan hükümlerde içermekte ve bu durum da aynı dönemde bölge Türklerine yönelik Bulgar politikasını etkilemektedir (Şimşir, 1986: 54-57). Türkiye'nin bağımsızlığını kazanması akabinde Türkiye ve Bulgaristan arasında 18 Ekim 1925'te Ankara imzalanan ikamet sözleşmesi ile Bulgaristan'dan Türkiye'ye göçler konusu hukuki temellere oturtuluyordu. Bu sözleşmenin içeriğiyle doğru orantılı olarak Türk göçlerini görmek mümkündür. 1923-1939 yılları arasında iki yüz bine yakın Türk Türkiye’ye göç etmiştir.

1930’lı y1llara gelindiğinde 1925 yılında imzalanan Türkiye-Bulgaristan dostluk ve ikamet antlaşmalarının gereklerine ters düşüldüğg̈̈, Bulgaristan'da yaşamlarını sürdürmekte olan Türkler üzerinde yeni yaptırımlara gidildiği görülmektedir. Yenisoy'a göre bu dönemde yeni yazı yasaklanmış ve birçok Türk Okulu kapatılmıştır. Yine bu kapsamda Bulgar yönetimi bir dizi karar alarak azınlık konumundaki Türklerin Türkiye ile kültürel bağlarını koparma ve birliklerini zayıflatma veya onları Türkiye'ye göçe zorlama gayretleri içine girmiştir. Bu kapsamda; Türkiye'ye göçü teşvik, aydın din adamlarını görevden uzaklaştırma, okullarda tekrar Arap harfleri ile eğitime geçme gibi politikalar uygulanmıştır (Yenisoy, 1997: 17).

$\mathrm{Bu}$ dönemde siyasal gelişmeler de çalkantılıdır. 1931 seçimi, seçmenlerin tercih ettikleri adaylara oy vermekte nispeten özgür oldukları son seçim olmuştur. Ülkeye rahat vermeyen siyasi, ekonomik ce sosyal sorunların bir araya gelmesi Mayıs 1934'te darbeye ve 1935'te 3. Boris'in idaresinde bir diktatörlük rejiminin kurulmasına yol açmıştır (Jelavich, 2009: 181). Bu aşamada 1944 yılında kurulacak Komünist sistemin ilk adımları atılmıştır, çünkü Jelavich'in de değindiği gibi, 1934 y1lında Sovyetler Birliği'yle ilk resmi ilişkiler kurulmuştur (Jelavich, 2009: 220).

Bulgaristan kurulduğunda birçok yörede Türkler çoğunluktaydı. Süreç içerisinde göçlerle bu çoğunluğun azaltılması yoluna gidilmiştir. 1934 sonrası Bulgarlar, bir toprak ihtilali yaparak Türklerin elindeki arazilere el koymuşlardır (Kekioğlu, 1985: 26-27). 1944'de yönetime gelen Komünist Parti liderleri, azınlık desteğini temin için önce baskı politikasına son vermiş, ancak 1946 sonrası özel okul statüsündeki Türk okullarını devletleştirmiş ve arkasından da tek tip bir sosyalist Bulgar toplumu oluşturma çalışmalarına başlamıştır (Turan, 1995: 295). 1934-1946 tarihleri arasındaki bu dönem Faşist Dönem olarak adlandırılmaktadır.

Burada Jelavich'in ifadesi önemlidir. Jelavich, Sosyalist Rejimin ilk yıllarında temel amacın geleceğin komünist toplumuna bir yol çizmek olduğunu düşünmektedir. Bu anlamda yapılan şey sadece yeni kurumlar kurmak değil, aynı derecede önemli görülen, hükümete düşman olduğu düşünülen organizasyonları veya "sınıf düşmanı" tabyası olan burjuvaziyi sindirmekti. Bu tutum kiliseleri, okulları, üniversiteleri ve bireysel yazarları ve sanatçıları çok derinden etkilemişti. Komünist hükümetlerin tamamı, basın, eğitim ve din de dahil olmak üzere ulusal kültürel hayat üzerinde güçlü bir sansürcü anlayışı kuramsallaştırmayı gerek görmüştür. Polis gücü ve mahkemeler de bu anlamda bir kontrolün sağlanması konusunda hükümetlere yardımcı olacaktır. Bu açıklamadan daha önceki tespitimizi geçerli kılmaktadır. Soykırım, asimilasyon, etnik temizlik ve milliyetçilik komünist rejimde yer bulan ifadeler değildir. Dolayısıyla tarihsel süreç değerlendirilirken farklı rejimler değil, hükümetler ve politikaları üzerinden hareket etmek faydalı olacaktır. 
1940 yılında Bulgaristan'ın eline geçen ve 1945'ten sonra da elinde bulundurduğu Güney Dobruca'da önemli sayıda Türk nüfus yaşamaktaydı. Bulgar hükümeti göç etmeleri için Türklere büyük baskılar uygulamıştır, çünkü Türklerin sahip oldukları toprakların devletleştirme politikasına dâhil edilmesi planlanmıştır (Jelavich, 2009: 395). Memişoğluna göre, bu dönemde asimilasyon politikası resmileşmiş, yeni hükümetin plânladığı ana politikalardan biri olduğunu bizzat komünist rejimin ilk Başbakanı Georgi Dimitrov, 6 Şubat 1946'da yaptığı konuşmada "Balkanların yalnızca Balkanlılara ait olmasını ve Slavların Balkanlarda başrolü oynamasını sağlamalıyız. Osmanlı İmparatorluğu'nun Balkanlara hükmettiği geçmiş zamanın nişaneleri tamamen silinmelidir." sözleriyle dile getirmiştir (Memişoğlu, 1999: 62). Bu noktadan itibaren azınlıkların asimilasyonu politikası hız kazanarak uygulamaya konulmuştur. Dayığlu'nun ifadesiyle, asimilasyona Pomaklardan başlanmış ve Dayığlunun da ifadesiyle, 1948-1952 yılları arasında devam eden bu süreçte Pomaklar küçük gruplar halinde ülkenin değişik bölgelerine sürülmüştür (Dayoğlu, 2002: 219).

10 Ağustos 1950'de Bulgar hükümeti, Türkiye'ye bir nota vererek Bulgaristan Türklerinden Türkiye'ye göçmen olarak alınmasını talep etmiştir. Bunun üzerine gergin olan Türk-Bulgar ilişkileri daha da kötüleşirken, karşılıklı bir nota düellosuna girilmiştir (Şimşir, 1986: 212-223). Bu nota ile Bulgaristan, ülkesinde yaşayan 250.000 Türkün Türkiye'ye göç etmek istediğini, Bulgar makamlarının bu kimselere göçmen pasaportu vermeye başladığını, 10 Ağustos 1950 tarihine kadar 54.028 kişiye pasaport verdiğini ve 250.000 kişinin hepsine pasaport verebileceğini bildirmiştir (Şimşir, 1992: 58). Bunun ardından bitmeyen göç yeniden başlamış ve sınır aşımı gerçekleşmiştir. Bulgaristan'ın bu notası sonucu, Ağanoğlu'na göre, 1950-1952 yılları arasında 154.393 Türk Bulgar sınırını geçerek Türkiye’ye gelmiştir (Ağanoğlu, 2001: 319).

Ancak bu aşamada belirtilmesi gereken önemli bir nokta daha vardır ki zannımızca Bulgaristan'ın Türk azınlık üzerindeki yaptırımlarının ana hatlarından birini oluşturmaktadır. Türkiye'nin Tarım Bakanlığı 31 Temmuz 1950 tarihinde dış işleri Bakanlığına aşağıdaki gibi bir görüş sunar: "Gerek serbest göçmen sıfatıyla gerekse memleketimizde yakınları bulunmadığından dolayı bu şekilde yurdumuza gelmek imkânlarına malik olmayan 500 bini mütecaviz soydaşımızla, 250- 300 bin kadar Pomak'in bir hamlede memlekete kabul edilmelerinin ve bunların kendi kendilerine geçimlerini sağlayabilecek bir seviyeye ulaşmalarının mümkün olamayacağı aşikârdır. ...Mevcudu 150 bin aileden aşağı olmayan Bulgaristan'daki Türk ve Pomak unsurunun iskanlı göçmen olarak yurda kabulleri ve yerleştirilip müstahsil hale getirilmeleri ortalama olarak 700-750 milyon liralık muazzam bir tahsisata mütevakkıf bulunmaktadır. Ehemmiyet ve azameti meydanda olan bu göç işinin, elde edilecek mali imkanların müsaadesi nispetinde, senelere sari bir şekilde ve her türlü icap ve imkanları telif edici bir plan ve program dahilinde ele alınmasını ve bu sene ancak serbest göçmen olarak gelmeyi göze alanlardan 25-30 bin kişinin yurda kabulleri yoluna gidilmesini..." (Şimşir, 1986: 219).

Bunun üzerine Türkiye'nin Dışişleri Bakanı " “ırkdaşlarımızın mühim bir kısmının muhtelif senelere dağıtılmak suretiyle peyderpey getirilmeleri bakanlığımızca mümkün görülmektedir" açıklamasını yapar (Şimşir, 1986: 220). Bu açıklamalar 1şı̆̆ında açıkça söylenebilir ki Türkiye tarafından Bulgaristan'a yapılacak bir müdahale zamanında gelmemiş, Türklerin bütçe ve istihdam sorunu nedeniyle göçleri zamana yayılarak, bir bakıma Türkler, kaderlerine terk edilmiş görüntüsünün ortaya çıkmasına sebebiyet verilmiştir. Toğrol'un belirttiği gibi, 1950-1951 yıllarını kapsayan dönemde toplam 154.393 Türk Bulgaristan'dan Türkiye'ye göçmen olarak gelmiştir (Toğrol, 1989: 73). Buradan da anlaşılacağı üzere 250.000 ile 300.000 arasındaki kişi sayısının telaffuzuna rağmen Türkiye'ye gelen kişi sayısı sadece yüzde ellisi kadardır. Bütün bu açılamalardan da görüleceği üzere Türkiye Bulgaristan'da yaşayan Türklerine sahip çıkmakta

\footnotetext{
${ }^{8}$ Dönemin Dış İşleri Bakanı Fuat Köprülü’dür.
} 
yetersiz kalmaktadır. Aynı tablo 1989 göçü esnasına sınırın kapatılması ve tekrar açılması süresince de görülecektir.

Bunun üzerine Türkiye'nin Dışişleri Bakan19 "ırkdaşlarımızın mühim bir kısmının muhtelif senelere dağıtılmak suretiyle peyderpey getirilmeleri bakanlığımızca mümkün görülmektedir" açıklamasını yapar (Şimşir, 1986: 220). Bu açıklamalar 1şığında açıkça söylenebilir ki Türkiye tarafından Bulgaristan'a yapılacak bir müdahale zamanında gelmemiş, Türklerin bütçe ve istihdam sorunu nedeniyle göçleri zamana yayılarak, bir bakıma Türkler, kaderlerine terk edilmiş görüntüsünün ortaya çıkmasına sebebiyet verilmiştir. Toğrol'un belirttiği gibi, 1950-1951 y1llarını kapsayan dönemde toplam 154.393 Türk Bulgaristan'dan Türkiye'ye göçmen olarak gelmiş̧tir (Toğrol, 1989: 73). Buradan da anlaşılacağı üzere 250.000 ile 300.000 arasındaki kişi sayısının telaffuzuna rağmen Türkiye'ye gelen kişi sayısı sadece yüzde ellisi kadardır. Bütün bu açılamalardan da görüleceği üzere Türkiye Bulgaristan'da yaşayan Türklerine sahip çıkmakta yetersiz kalmaktadır. Aynı tablo 1989 göçü esnasına sınırın kapatılması ve tekrar açılması süresince de görülecek, bu konu daha kapsamlı irdelenecektir.

Komünist rejim döneminde Bulgaristan'da sanayileşme ve ağır sanayi geçiş çabalarında konunun sosyal boyutu düşünülmemiş, köyler boşaldı. Diğer taraftan kooperatiflerin yaygınlaşması ve özel mülkiyetin yasaklanması, tarımsal ve zirai üretimde verimsizliğe neden olmuştur. Bu durum, bir tarım ülkesi olan Bulgaristan'ın dış pazarlara tarımsal ürünler ve kaliteli sanayi mamulleri satamamasını beraberinde getirir (Çavuşoğlu, 2001: 73-75). 1949-1956 yılları arası dönemde toprakların devlet politikası gereği kollektifleştirilmesi, Bulgaristan'da yaşayan Türkler açısından ciddi bir maddi kayba ve ağır bir buhrana sebep olmuştur.

Bulgaristan, kurulduğu günden itibaren sistemli bir şekilde Türk azınlığ1 yok etmeye çalışmış, bu amacın son halkalarından birisi olarak 17 Temmuz 1970'da Bulgaristan Merkez Politbüro yetkilileri 549 sayıl "gizli tedhiş ile milliyet ve din değiştirme" kararı almışlardır (Toğrol, 1989: 74-75). Bu karar milliyetçiliğin sinyallerini vermektedir. Toğrol'a göre, Bulgarları bu tür "çılgın karar" ve uygulamalara iten nedenlerin başında, Türklerin hızlı nüfus artışı karşısında ${ }^{10}$ Bulgarların zamanla azınlığa düşme endişesi yatmaktadır. Nitekim bu kaygılar, çeşitli resmi toplantı ve raporlarda dile getirilmiştir (Toğrol, 1991: 50-65).

1969 yılında başlayan göç dalgasının nedenleri arasında, mevcut siyasal politikaların ve milliyetçilik adı altındaki asimilasyonun getirdiği baskı rejiminin dışında, 1950-51 göçünün etkilerine rastlamak mümkündür. Bu bağlamda son göç ile parçalanan ve aile birliği dağılan Türkleri bir araya getirmek ana etmenler arasındadır. 1968 yılında, 8 Ekim 1969'da ilk göçmen kafilesi Edirne Karaağaç istasyonuna gelmiştir. Şimşir'in de değindiği üzere, bunu izleyen on yıl boyunca da her hafta (Aralık-Mart ayları hariç) göç kafilelerinin gelmesi sürmüş ve bu kapsamda gelen göçmen sayısı tüm tahminlerin aksine 130.000 gibi büyük bir sayıya ulaşmıştır (Şimşir, 1986: 319-338).

1980'li yıllara gelindiğinde aynı tabloyla karşılaşılmaktadır. Toğrol'a göre, Türklerin milli ve dini benliklerini korumaları, komünist ideoloji ve diğer benzeri propagandalardan etkilenmemeleri de Bulgar yönetimini telaşa ve kendi açılarından acil çözümler aramaya sevk etmiştir. Toğrol bu durumu Türklerin bir özelliğine, güçlü aile yapısına sahip olmalarına dayandırmaktadır (Toğrol, 1991: 65-68).

1960 yılında Bulgaristan Komünist Partisinin ağırlığının hissedildiği bir toplantıda nüfus yasasında yapılan bir değişiklikle Bulgar soyundan olmayan vatandaşların kendi istekleri ile isim ve

\footnotetext{
${ }^{9}$ Dönemin Dış İşleri Bakanı Fuat Köprülü’dür.

${ }^{10}$ Bulgaristan'da yaşayan Türklerin hızlı nüfus artışı, üzerinde durulması gereken etmenler arasındadır. Burada toplum sosyolojisi dalına giren ve çalışma konusu olarak değerlendirilebilecek bir sorunsalı ön plana çıkarmakta fayda vardır. Yıllarca resmi ya da gayrı resmi politikalar yürütülerek baskı rejimlerine direnç gösteren Türklerin bilinçli bir çoğalma yoluna gittikleri düşünülebilir.
} 
soyadlarını değiştirebilecekleri kararı alınmıştır. Nüfus yasasında yapılan bu değişikliğe rağmen Türklerden bir kişi bile isim değiştirmek için 1960-1984 yılları arasında müracaatta bulunmamıştır. Ancak Bulgarlar bunu 1984 yılı aralık ayında başlattıkları isim değiştirme politikasının yasal dayanağı olarak kullanmışlardır (Şimşir, 1986: 14). Bu sancılı süreçte tarlaları kooperatifleşme adı altında, okulları daha iyi eğitim verme amacıyla ellerinden alınan, dinsel yaşamına ve geleneksel yaşamına müdahalede bulunulan Türkler Türkiye'ye göç etme fikrini benimsemiştir (Şimşir, 1986: 167).

Zorla isim değiştirme işlemine önce Pomaklardan başlanmış ve adları 1972-1974 arası zorla değiştirilmiştir. ${ }^{11}$ Arkasından Türk-Bulgar ilişkileri en iyi seyrettiğ 1981-1983 arası dönemde aynı işlemler Müslüman Çingenelere tatbik edilmişidir (Şimşir, 1986: 339-353). Bunun ardından süreç ülke çapında yaygınlaştırılmış ve isim değiştirmenin dışında dini yasaklamalara kadar ilerletilmiştir. Şimşir'e göre, eğitim müfredatları ve Türkçe eğitim yasaklanmış, Türkler sürekli Türkiye'ye göçe zorlanmış ve resmi teşviklerle ad değiştirmeye zorlanmış ama yine Türk varlığ kaldırılamamıştı. 1960'dan itibaren Bulgaristan'daki Türkler, "Müslümanlaşmış Bulgarlar” şeklinde tarih saptırılarak inkâr edilmeye çalış1liyordu (Şimşir, 1986: 354-364). Dört milyon dolayında olduğu tahmin edilen Bulgaristan Türkleri, kendilerine uygulanan her türlü bask1 ve yok etme planlarına rağmen milli kültür ve benliklerini korumaya çalışmışlardır (Toğrol, 1991: 70-119).

İktidara gelen Tofdot Jivkov 1984-1989 y1lları arasında devlet eliyle yürütülen resmi asimilasyon politikasının mimarı olarak anılmaktadır. Jivkov'un, Bulgaristan siyasi hayatında yeni bir kırılma noktası yaratan ilk icraatı ise 1971 Anayasası olmuştur. Yeni anayasaya göre, azınlık kavramı Anayasa'dan çıkartılmış, Türk okulları ve Türkçe kursları kademeli olarak kapatılarak, "Türkçe" seçmeli ders olarak haftada 2 saate indirilmiştir. Ayrıca bir süre durulan isim değiştirme kampanyasına yine Pomaklardan başlanarak yeniden başlanıldı. 1984 kışı itibarıyla da ülkedeki Türklere yönelik "yeniden doğuş"12 olarak adlandırılan Bulgarlaştırma politikası resmi olarak hayata geçirilmiş, bu bağlamda büyük ölçekli bir asimilasyon kampanyası başlatılmıştır. Pomakların isimlerinin değiştirilmesiyle 24 Aralık 1984 tarihinde Doğu Rodop ve Balkan Kotel merkezli başlayan süreç 19 Ocak 1985 yılına kadar Bulgaristan'da yaşayan Türklerin tamamını ${ }^{13}$ kapsayarak devam etmiştir. 17 Nisan 1986 'da bu sürecin gerçekleşmesine yaptıkları katkıdan dolayı İçişleri Bakanlığı'ndaki yöneticiler ve üst düzey subaylardan oluşan 179 kişiye Jivkov'un eliyle devlet nişanı verilmiştir.

22 Şubat 1985 'te Bulgaristan'a bir nota veren Türkiye, "geniş kapsamlı bir göç anlaşması da dâhil olmak üzere sorunların görüşmeler yoluyla çözülmesini” önermiş (Şimşir, 1987: 65), ancak Bulgaristan notada yer bulan teklifi reddetmiştir. Toğrol'un belirttiği üzere, Bulgaristan Türklerinin çile ve 1stırapları, aynı yılın mayıs ayında Türkiye'ye büyük bir göç dalgası yaratmış ve kısa sürede göçmen sayısı üç yüz on üç bine ulaşmıştır (Toğrol, 1989: 1-2). Bu aşamadan sonra Trük Hükümetinin sınırları açmaktan başka çaresinin kalmayış1 1989 göçünün seyrini değiştirmiş̧ir. Ağanoğlu'na göre, 23 Ağustos 1989 tarihine gelindiğinde Kapıkule sınır kapısından giriş yapan göçmen sayısı 310.000'e ulaşmıştır (Ağanoğlu, 2001: 316). 1989 göçünde de daha önceki göçlerde olduğu gibi Türkiye'nin müdahalesi gecikmiş, Bulgaristan'da yaşayan Türklerin katli notalar verilerek ve yaptırımda bulunacak yollar arayışına girmeyerek izlenmiştir. Gömeç’e göre, 1989 Göç Hareketinden öncesinde, 1984-1985 yıllarında yapılan soykırım faaliyetlerine yönelik olarak Türkiye'de gerekli hassasiyetin gösterilmemesi, siyasi parti yöneticilerinin Bulgar yönetiminin

\footnotetext{
${ }^{11} \mathrm{Bu}$ aşamada zorla isim değiştirilmelere öncelikle Pomaklardan başlanması ilgi çekicidir. Dama önce de değinildiği üzere Bulgar istatistikler Pomakları Bulgar olarak nitelendirilmektedir. Pomakların Bulgarlara yakın olarak benimsenmesi, isim değişikliği sürecinde kamuoyundan gelecek tepkilerin azaltılması açısından politik bir yol olarak benimsenmiş, yumuşak bir geçişle değişiklik planlanmıştır.

${ }^{12}$ Възродителен процес

${ }^{13}$ Bu dönem içerisinde Bulgaristan dışında olan Türk asıllı Bulgar vatandaşları bulundukları ülkelerden mahkeme kararıyla çağırılarak zorla isimleri değiştirilir.
} 
politikalarını kınamaktan öteye gidememeleri; Türkiye'de olan en ufak bir hukuksuzlukta ayağa kalkan Avrupa ve diğer Birleşmiş Milletler ülkeleri, Bulgaristan'daki mezalimin üzücü olduğunu belirtmekten başka hiçbir şey yapmamaları ayrı bir nüanstır (Gömeç, 1999: 248).

Türklerin Bulgaristan'dan göçlerini irdeleyen birçok çalışmada özellikle üzerinde durulan nokta adı geçen göçlerin Komünist rejimin baskı ve dayatmaları sonucu ortaya çıktığını vurgulanmakta, toplumsal yer değiştirmeleri siyasal bir rejimin politikası olarak sunulmaktadır. Ancak daha önce de değinildiği üzere, tarihsel perspektifte değerlendirildiğinde bu kanının çok da doğru olmadığı ortaya çıkmaktadır. Genel tabloya bakıldığında Bulgaristan'da yaşayan Türklerin baskılar sonucu azınlık durumuna düşürüldükleri andan itibaren de her aşamada resmi ya da gayrı resmi bir asimilasyon politikasının Bulgar makamlarınca yürütüldü açıkça görülmektedir. Bunun yanında günümüz siyasal oluşumlarında azınlıkların her zaman bir sorun olarak görüldüğü eklenmelidir. Dolayısıyla azınlık kavramı söz konusu olduğunda asimilasyon sürecinin tek bir siyasi sisteme bağlandırılması kanımızca yanlış olacaktır.

\section{3- Bulgaristan'da Azınlıkların Hak ve Özgürlüklerinin Hukuki Boyutu}

Osmanlı İmparatorluğunun 1877-1878 Osmanlı-Rus Savaşından yenik çıkması ve topraklarında Bulgar Prensliği kurulmasını kabul etmesi bu topraklarda yaşamlarını sürdüren Türklerin azınlık durumuna düşmesine neden olmuştur. Lütem'e göre, savaştaki kayıpların yanı sıra geriye kalan halkta ekonomik ve kültürel bakımdan elit tabaka Anadolu'ya göç etmiş, geriye fakir, savunmasız, haklarını aramakta yetersiz, kırsal kesimde yasayan bir toplum profili kalmıştır (Lütem, 2000: 59). Bu durum Türklerin azınlık haklar1 konusunda revizyona gidilmesini ve uluslararas1 anlaşmalarla pekiştirilmesini gerekli kılmıștır. Bulgaristan Anayasasında ve uluslararası platformda kendine yer bulan bu anlaşmalar bir taraftan yasal düzenlemeleri getirirken diğer taraftan Türkiye'nin Bulgaristan'da yaşayan Türkler üzerinde belirleyici bir sorumluluk yüklenmesini sağlamaktadır.

Bulgaristan'ın kendi iç hukukunun dışında meselenin uluslararası platformda tartışma bulması ve yasal yaptırımlar çerçevesine oturtulması aynı zamanda Bulgaristan üzerinde yaptırım sağlamaktadır. Bu durum hukuki boyutun Bulgaristan'ın kendi hukukunun da üzerinde tartışılmasını gerekmektedir. Bu bölümde tarihsel yapı içerisinde bazı anlaşmalara değinerek azınlık haklarına genel bir bakış sağlanacaktır. Bulgaristan'ın 2007 yılında Avrupa Birliğinin üyesi olması ve azınlık hakları konusunda yeni bir strateji belirlemek zorunda kalmas1 üzerinde durulması gereken bir konudur, ancak çalışmamız açısından düşünüldüğünde Bulgaristan'ın 1989 yılından itibaren taraf olduğu sözleşmeler konumuz dışında kalmaktadır ve göz önünde bulundurulmayacaktır.

\subsection{Bulgaristan Anayasası}

1878 Berlin antlaşmasıyla Bulgar prensliği ve Doğu Rumeli Eyaleti isimleriyle Osmanlıdan ayrılıp 1885 yılında Bulgar prensliğinin, kendisine ait olmayan Doğu Rumeli Eyaleti üzerinde hak iddia etmesiyle, ortaya çıkan Bulgaristan, 1908 yılına kadar yarı özerk bir yönetimle idare edilmiştir. Prenslik, 1908 yılında Osmanlı İmparatorluğunun uluslararası arenadaki zayıf pozisyonu nedeniyle kolay bir şekilde bağımsızlığını ilan etmiş ve 1944 yılına kadar monarşi ile yönetilmiştir. 1944'te iktidara gelen komünist parti 1989 y1lına kadar ülkeyi idare etmiş, 1989 yllında gerçeklesen sivil ayaklanma ile komünist parti devrilmiş ve demokrasiye geçilmiştir.

Bulgaristan bağımsızlığını kazandığı tarihten bu yana, dört anayasal metinle devletin işleyişini düzenlemiştir. Bunlardan ilki, 1879 tarihli Tırnovo Anayasasıdır ve monarşik temeller üzerine kurulmuştur. İkincisi 1947 tarihli Dimitrov Anayasası olmakla birlikte üçüncüsü 1971 tarihli Jivkov Anayasasıdır ve her ikisi de sosyalist temeller taşımaktadır. Son olarak 1991 tarihli Bulgaristan Cumhuriyeti Anayasasından söz etmek mümkündür. ${ }^{14}$

\footnotetext{
14“Bulgaristan Halk Cumhuriyeti" olarak anılmakta olan Bulgaristan, ismindeki "Halk" kelimesinin kaldırılmasıyla, "Bulgaristan Cumhuriyeti” olarak değiştirilmiştir.
} 
1877-78 Osmanlı-Rus savaşı sonrası Bulgar Prensliğinde Türklerin azınlık durumuna düşmesi azınlıklarla ilgili bazı yasal düzenlemelere gidilmesini zorunlu kılmış ve Tırnovo Anayasasında (1979) kendine ifade bulmuştur. Ancak bu anayasada açıkça azınlık kavramı kullanılmamakta, 40. Maddede farklı dini inançlara sahip olanların serbestçe dini vecibelerini yerine getirebileceği vurgulanmaktadır. Aynı anayasanın 57. Maddesi herkesin hukuk karşısında eşitliğine değinir.

Bulgaristan'da İkinci Dünya Savaşı'ndan sonra iktidara gelen Komünist Parti'nin, azınlıklara yönelik politikası dönemsel olarak değişlik gösterir. İktidarın ilk yıllarında, ülkedeki Türklere karşı eşit ve özgürlükçü politikalar benimsendiği görülmektedir. Sovyet Anayasası örnek alınarak hazırlanan 4 Aralık 1947 tarihli Bulgar Anayasası Dimitrov Anayasas $1{ }^{15}$ olarak anılmaktadır. $\mathrm{Bu}$ anayasada Türkler "ulusal azınlık" olarak değerlendirilmektedir. Anayasanın 71. maddesi "Bulgaristan Halk Cumhuriyeti’nin bütün vatandaşları yasalar önünde eşittir" hükmünü, 72. maddesi de "Tüm Bulgar vatandaşlarının din ve vicdan özgürlüğü bütündür ve herkes inandığı ibadetin gereklerini yerine getirmekte özgürdür" hükümlerini içermiştir. Aynı anayasanın 79. Maddesi gereğince ulusal azınlıkların kendi dillerinde eğitim görme hakları vardır ve kültürel faaliyetlerini devam ettirebilirler. Ancak bu maddede kendi anadillerinin yanında Bulgar dilini öğrenme zorunluluğu da eklenmektedir. Anayasada dikkat çekici unsur sadece Türklerin "ulusal azınlıklar" olarak tanımlanmasıdır.

Genel anlamda bakıldığında bu madde ile din ve vicdan özgürlüğüne değinerek sağlıklı bir azınlık statüsü değerlendirmesi yapsa da, Özgür'e göre, 4 Ocak 1948 tarihinde Bulgaristan Komünist Partisi Merkez Komitesince alınan bir kararla Türk azınlık "ülkenin bir kısmından kurtarılması gereken verimsiz ve potansiyel güvensiz bir unsur" olarak ilân edilmiştir. Alınan bu karardan sonra Başbakan Dimitrov Bulgaristan Komünist Partisi toplantısında yaptığ 1 bir konuşmada Bulgar olmayan etnik grupları "toplumun kanayan yarası" olarak dile getirmiş ve Türk azınlık için bir komisyon kurulması kararlaştırılmıştır (Ö̈zgür, 1999: 72). Hukuki açıdan bakıldığında 1947 tarihli Dimitrov Anayasası din ve vicdan özgürlüğ̈ bağlamında eşitliğe değiniyor olsa da bu kavramların anayasada kalmaktan öteye geçmediği ve uygulamada etkinlik göstermediği açıktır.

18 Mayıs 1971 tarihli Bulgaristan Anayasası Jivkov Anayasas $1{ }^{16}$ olarak anılmaktadır. Bu anayasada azınlık statüsü tamamen ortadan kalkmakta ve yerine "bulgar asıllı olmayan vatandaş" tanımı getirilmektedir. Bu anayasa asimilasyonun temellerini de bu ifadeyle atmaktadır. Anayasanın 45/7. Maddesine göre Bulgar asıllı olmayan vatandaşların Bulgar dilini öğrenmeleri ve eğitim görmelerini zorunlu kılınmakta, bunun yanında kendi dillerini öğrenme ve eğitim görme hakları da bulunmaktadır.

Tarihsel süreç değerlendirildiğinde devlet ve parti yönetiminin bu anayasal düzenlemeleri uygulamaya koyma konusunda dönemsel değişiklikler gösterdiği görülmektedir. Bu değişken tutum kimi zamanlarda, örneğin politbüronun 26 Nisan 1951 tarihli kararına göre Türklere Bulgarca ve/veya Türkçe gazete ve dergi çıkarma hakkı tanınmaktadır. Bu dönemde Türklerin Türkçe ve/veya Bulgarca 10 gazete ve 1 dergi çıkarması olumlu bir gelişme olarak nitelendirilebilir. Aynı dönemde Bulgaristan devlet Radyosu düzenli Türkçe yayınlar yapmakta ve bazı şehirlerde (örneğin Şumen) Devlet Tiyatrosu Türk piyesleri sahneye koymaktadır. Buna karşı1ık bazı dönemlerde bu düşünceye tamamen zıt bir çizgi izlenmiştir. 1956 yılında $\mathrm{BKP}^{17}$ Genel Başkanlığına Todor Jivkov'un geçmesi, farklı bir politik yol izlenmesi sonucunu doğurmuştur. Politbüro 21 Haziran 1958 tarihinde Türk ve Bulgar okullarını birleştirme kararı almıştır. Bu dönemde Türklerin yayımladıkları gazete sayısı azalırken, zaman içerisinde yayımlar tamamen Bulgarca diline dönmüş, Devlet Tiyatrolarının sahneledikleri Türk piyeslerine son verilmiştir.

\footnotetext{
${ }^{15}$ Bulgaristan Devlet Gazetesi (държавен вестник) 06.12.1947, sayı: 284.

16 Bulgaristan Devlet Gazetesi (държавен вестник) 1971, sayı: 39.

${ }^{17}$ Bulgar Komünist Partisi.
} 
1971 anayasasının terk edilmesi ve 1991 anayasasına geçilmesi Bulgaristan için sancılı bir süreç sonucunda gerçekleşir. Dünya siyasal haritası değişikliğe uğramış, 1989 yılında Sovyetler Birliğinin dağılması ve serbest piyasa ekonomisine geçmesiyle, Bulgaristan da fazla direnemeyerek Komünist sistemden Kapitalist sisteme hızlı bir geçiş yapmıştır. Dolayısıyla sosyalist bir anayasadan serbest piyasa ekonomisi seçimini yansıtan anayasaya geçilmiştir. Bu anayasa Bulgaristan Anayasası olarak adlandırılmaktadır. Anayasanın 25. maddesine göre, annesi ve/veya babası Bulgar vatandaş1 olan veya Bulgaristan Cumhuriyeti topraklarında doğan herkes kökeninden dolayı başka bir ülkenin vatandaşlığına hak kazanmadıkça Bulgar vatandaşıdır. Bulgar vatandaşlığının edinilmesi, devamı ve kaybedilmesine ilişkin şart ve usuller kanunla düzenlenir ${ }^{18}$. Bu madde kapsamında anne ve veya babanın Bulgar vatandaşı olması, Bulgar topraklarında doğmak gibi etkenler kişinin dolaysız olarak Bulgar vatandaşı olarak değerlendirilmesi için yeterli sebeplerdir. Görüldüğü üzere bu anayasada azınlık konusuna yer verilmemekte, mevcut koşullarda herkes Bulgar vatandaşı ilan edilmektedir.

Genel olarak değerlendirildiğinde, devletin 1989 y1lına kadar uygulamış olduğu politika Türklerin Bulgarlaştırılmasına yöneliktir. Bunu anlamak için dönemsel olarak Bulgaristan'da Türkçe diline olan yaklaşıma bakmak yeterlidir. Bulgaristan'ın kuruluş yıllarında Türklerin sadece anadilde eğitim aldıkları görülmektedir, yapılan anayasal değişikliklerle anadil eğitimin yanında Bulgarca dilinde eğitim de zorunlu getirilmiş, zaman içinde Bulgarca tek dil olarak benimsenerek Türkçe dersleri seçmeli hale getirilmiştir. Azalan seçmeli Türkçe ders sayıları 1974'te tamamen yasaklanarak kaldırılmıştır. ${ }^{19}$ 1985-1989 yılları arasında ise Türkçe konuşma yasağı getirilmekte, Türkçe konuşanlara cezai sorumluluk yüklenmektedir.

\section{2. İkili ve Çok Taraflı Anlaşmalar}

Bulgaristan'ın özerkliğini ilanı ile birlikte dahil olduğu ikili ya da çoklu anlaşma, sözleşme ve protokoller genel anlamda azınlıkların hak ve özgürlüklerini, inanç ve yaşam biçimlerini, eğitim ve meslek tercihlerini güvence altına almaktadır. İmzalanan çoklu anlaşmalar Bulgaristan'a Türkiye dışındaki devletlere karşı da bazı yükümlülükler getirmesine rağmen bu yükümlülükler yerine getirilmemiş ve anlaşmalar kâğıt üzerinde kalmıştır. Özellikle Bulgaristan'dan Türkiye’ye göçlerin s1klığı göz önünde bulundurulduğunda Bulgaristan'da yaşayan azınlıkların sahip olduğu hukuki haklardan yararlanamadıkları söylenebilir.

\subsubsection{Berlin Antlaşması}

1877-78 Osmanlı Rus Savaşının ${ }^{20}$ sonucunu bağlayan Berlin Anlaşması, Osmanlı Rus Savaşına son veren ve Rus isteklerini barındıran Ayastefanos Anlaşmasının şartlarının belirlenmesi niteliği taşımıştır. Berlin antlaşmasıyla özerkliğini kazanan Bulgaristan Prensliğinde mevcudiyetini korumakta olan azınlıklarla ilgili bir düzenlemenin yapılması ihtiyaç olmuştur. Sander'e göre Türklerin ilk kez azınlık durumuna düştüğü Berlin Antlaşmasında Türklerle ilgili olarak ilginç düzenlemelerin varllğ 1 dikkati çeker (Sander, 2001: 315). Bunlardan en önemlisi, Şimşir'in de belirttiği üzere Türk-Müslüman Azınlık" için "Türk" kavramı kullanılmasıdır. Ek olarak, antlaşmanın içeriğinde Bulgarlarla Türklerin karışık olduğu yerlerde Türklerin "hukuk ve menfaatlerinin gözetileceği” belirtilmesi de önemlidir (Şimşir, 1985: 366). ${ }^{21}$. Anlaşmanın 3. Maddesi şöyledir: “...gerek prensin seçiminde gerek Bulgar anayasasının hazırlanmasında Bulgaristan Türklerinin hak ve çıkarlarının gözetileceği..." (Şimşir, 1986: 241). Anlaşmanın 5. Maddesi ise şöyledir:

"Bulgaristan'da hukuk ve umumiyenin esas1 atide muharrer maddelerden ibarettir. Bulgaristan'da ihtilaf-1 din ve mezheb, hiç kimse için hukuki milkiye ve memuriyet ve şerefine

\footnotetext{
${ }^{18}$ Tam metin için bkz. http://www.parliament.bg/en/const, "Erişim: 27.07.2013".

${ }^{19}$ Bkz. Bulgaristan Milli Raporu, 2001.

${ }^{20}$ Osmanl1-Rus savaşı bazı kaynaklarda 93 harbi olarak geçmektedir.

${ }^{21}$ ŞìSŞiR, (1985), s.366.
} 
nailiyetde veya her nerede olursa olsun icra-yi hırfet ve sanatde nachil tutulmaklığa ve mahrum idilmekliğe sebep addolunmıyacaktır.

Bulgaristan'da yerlüler ve ecnebilere serbesti ve icray-i ayin ve mezhep temin olunarak gerek cemaat-i muhtelifiyenin silsile-i meratip üzre tertibinde ve gerek rüjsa-yi ruhaniyeleriyle olan münasebatındaika-i mevani olunmıyacaktır (Şimşir, 1985: 253-254).

Buna göre anlaşma, Türklere dini, kültürel haklar tanınacağını ve bunların hiçbir şekilde engellenmeyeceğini ön görmektedir:" Bulgaristan'da din ve mezhep ayrımı gözetilemez. Ayrı din ve mezhepten olan azınlıklar, tıpkı Bulgar çoğunluk gibi bütün medeni ve siyasal haklardan yararlanırlar. Bulgar Hükümeti, azınlıklara 'din ve ayin özgürlüğü' sağlamakla yükümlüdür. Azınlıkların kendi dini liderleriyle olan ilişkileri engellenemez" (Şimşir, 1986: 366). Bunun yanında:

"Bulgaristan prensi ehali tarafindan serbestçe intihab ve devletler muvafakatile canib-i Bab1 Aliden tasdik olınacak ve Avrupa düvel-i muazzamasınının hanedan-1 hükümdarileri azasından hiçbiri Bulgaristan prensliğine intihab idilmeyecekdir" (Erim, 1953: 404-407).

ifadesi kullanılmaktadır. Antlaşmaya göre Bulgaristan Prensi ahali tarafından serbestçe seçilecek ve büyük devletlerin muvafakatiyle Babıali tarafından da tasdik olunacaktı. Görüldüğü üzere bu maddeler Türk azınlığın haklarını korumaktadır ancak uygulamada nasıl hayat bulduğu üzerine tartışmalara açıktır. Memişoğlu'na göre, 5. maddede belirtilen azınlığın haklarını ve milli kültür kurumlarını koruma hakkına ilişkin olan husus ihlal edilmiş, Türk azınlığa ait diğer mimari unsurlar da bu yıkımdan nasibini almıştır. Geride kalan sağlam yapılar ise Prenslik yönetimince Türk azınlığın elinden alınmış ve karşılıksız olarak kamulaştırma işlemine maruz bırakılmışlardır (Memişoğlu, s. 74-75).

Bunun yanında üzerinde durulması gereken önemli noktalardan biri de Türklerin taşınamaz varlıkları ile ilgilidir. Berlin Antlaşması'nın 12. maddesi uyarınca, Türkler, Bulgaristan'dan göç etmiş veya ayrılmış bile olsalar geride bırakacakları mülklerini koruyabilirler. $\mathrm{Bu}$ taşınmazların sahipleri Bulgaristan'dan ayrıldıklarında Bulgar devlet makamlan bunlara el koyamayacaktır (Şimşir, 1986: 366). Ayrıca bu madde kapsamında Erim'e göre, Türkler Bulgaristan'dan göç etmiş olsalar dahi Bulgaristan'daki mülklerini üçüncü kişiler aracılığıyla işletebilirler (Erim, 1953: 409). Bu madde her ne kadar Bulgaristan'ı terk eden Türklerin geride kalan maddi varlıklarını korumaya yönelik olsa da sonraki dönemlerde Bulgaristan tarafı bu anlaşmayı hiçe saymıştır. Bu bağlamda düşünüldüğünde Türklerin Bulgaristan'1 terk etmeyerek ülkede kalmaları daha anlaşılır olmaktadır. Şimşek'in de değindiği üzere, bu antlaşma ile Bulgar Prensliği, Türklere her türlü serbest yaşama olanağını vermeyi taahhüt ettiği halde, bu antlaşmanın hükümleri hiçe sayılmış, Türk azınlığa karşı "parçala-yönet" politikalarına girişilmiş ve Türk nüfus İmparatorluk Türkiye'sine göçe zorlanmıştır (Şimşek, 1999: 89).

\subsection{2. İstanbul Protokolü ve Sözleşmesi}

1908 yılında bağımsızlığını kazanan ve Bulgaristan, 19 Nisan 1909 tarihinde Osmanlı İmparatorluğu ile İstanbul Protokolünü ve buna bağlı olan sözleşmeyi imzalayarak mevcut azınlıklar konusundaki hak ve güvenceleri yeniden yasal düzenlemeler içerisine almıştır. Bu protokolle Berlin antlaşmasında Bulgaristan'da yaşayan ve azınlık konumunda bulunan Türklere verilen hak ve özgürlükler korunmaktadır. Protokolün 2. Maddesine göre:

"Cemaat-i İslamiyenin ve efkafın suret-i tensıkına müteallik olan melfuf suret-i tesviye işbu mukavelenamenin cüz-i gayr-i mufariki addolunacak ve aynı zamanda imza edilecektir. Ahali-i İslamiyeye kemakan serbesti-i ayin temin edilecektir. Bunlar Mezahib-i saireye mensup ahalinin haiz oldukları ayni hukuki medeniye ve siyasiyeden istifadeye devam edeceklerdir. Cevami-i şerifede Halife-i Müslimin sıfatıyle nam-1 name-i Padişahiye hutbe kıratına devam edilecektir. Efkaf-1 müstesnaya gelince Bulgaristan Hükümeti nihayet üç ay müddet zaafında bir idare komisyonu teşkil 
edecek ve bu komisyon alakadaran tarafından dermeyan ounacak metalib ve müddeiyatın hak ve sevaba mukaremetini tetkik eyleyecektir (Şimşir, 1985: 368).

Bunun yanında bu protokole göre, Bulgaristan'daki Türk-İslam eserleri Bulgaristan'ın bir iç sorunu olmaktan çıkarak Devletler Hukuku güvencesi altına alınmış ve Türk Hükümeti gerek Bulgaristan'daki Türk Azınlık gerekse Bulgaristan'daki Türk-İslam Kültürüne ait eserler üzerinde hak sahibi olmuştur (Kamil, 1989: 17). Protokolle birlikte aynı gün imzalanan sözleşme, müftülükleri düzenleme amacı taşımıştır. Müftüler arasında bir baş müftü seçimini öngören bu sözleşmeye göre baş müftünün görevleri düzenlenmiştir. İki hükümet arasında iletişimi sağlayacak olan baş müftü seçimle başa gelecek, ancak göreve başlaması için şeyhülislamdan onay alması beklenecek, bu izin baş müftüye diğer müftülerin görev ve yetkilerini belirleme görevi yüklemektedir.

Lüten'e göre, bu protokol ve bağlı bulunduğu sözleşme ile Bulgaristan'daki Türk azınlığın her türlü medeni ve siyasi haklardan faydalanabileceği, aynı şekilde hak eşitliğine, din ve mezhep hürriyetine sahip olabileceği teyit edilirken; Türklerin okullarını, cami veya mescitlerini koruyup yaşatabilecekleri vurgulanmıştır (Lütem, 2003: 45). Dikkat edilirse Berlin Antlaşması Türk nüfusunun Bulgar nüfusu ile sahip olduğu siyasi ve medeni hakların eşitliğini vurgularken İstanbul Protokolü ve eşliğindeki sözleşme dini hak ve özgürlüklere ayrıntılı olarak değinmekte mezhep özgürlüğ̈ sunmakta, ibadet yerlerinin korunma ve yaşatılmasına vurgu yapmaktadır.

\subsubsection{Tarihli Antlaşma ve Müftülerle İlgili Sözleşme}

Balkan Savaşları sonunda imzalanan Osmanli İmparatorluğu ile Bulgaristan arasında 29 Eylül 1913 tarihli bu anlaşmanın 1-12. Maddeleri, Koyuncunun da belirttiği üzere, Bulgaristan'da kalan Türkleri kapsarken,13-22. maddeleri ise Doğu Rumeli'yi ilgilendiriyordu. Antlaşma, 1908 yılına kadar Osmanlı-Bulgaristan ve Bulgaristan-Düvel-i Muazzama ilişkilerini düzenlemiş̧tir (Koyuncu, 2005: 211). Ekteki sözleşme müftülerin görev ve yetkileri bağlamında değerlendirilebilir. alınmıştır.

Sözleşmenin 8. Maddesi Bulgaristan'da yaşayan Müslümanların ${ }^{22}$ hak ve özgürlükleri ele

"Bulgaristan bilcümle memlikinde Bulgar tebaasından bulunan Müslümanlar Bulgar olan tebaanın haiz oldukları hukuki mülkiye ve siyasiyeyi haiz ve serbesti-i vicdana, hürriyet-i dininyeye ve ayin-i dinin alenen icrası hususunda serbestiye malik olıcaklardır. Müslümanların adatına riayet olunacaktır (Gündüz, 1985: 40).

$\mathrm{Bu}$ antlaşmaya göre, Bulgaristan'a bırakılan topraklardaki Türk-Müslüman nüfus Bulgar uyruğuna geçerken, 4 yıllık bir süre içerisinde fikri değiştiyse Türk uyruğuna geçebilme şansını elinde tutabiliyordu. Çocuklarda reşit olduktan sonra bu hakka sahip olabilmekteydi. Ancak Türk uyruğuna geçmek isteyenlere 4 yıl içinde Türkiye'ye göçmek zorunluluğu getiriliyor, taşınır eşyalarını ve mal varlığını götürebiliyor ve bunlar için gümrük parası ödemiyorlardı. Bunun yanında, Bulgar uyruğunda kalmayı tercih eden Türk azınlık, Bulgarların sahip olduğu her türlü medeni ve siyasal haklardan yararlanabiliyordu (Hakov, 2002: 41). Azınlık olan Türklerin her türlü hak ve özgürlüklerine değinildiği yanılgısı taşıyan bu anlaşmada taşınamaz mallara değinilmemekte ve Bulgaristan lehine bir açık bırakılmaktadır. Göç ile ilgili hususların düzenlenmesi, Türklerin mal varlıklarını güvence altına alıyormuş gibi görünse de tarihte gördüğümüz ve Turan'ın da değindiği üzere Bulgaristan'da yaşayan Türkler bu sözleşmenin kendilerine tanıdığı haklarda olduğu gibi, istediği zaman, malvarlığını da yanına alarak değil; Bulgar yönetiminin istediği kısıtlı zamanlarda, çoğu zaman mal varlığını terk ederek göç etmişlerdir (Turan, 1995: 22-25).

$\mathrm{Bu}$ antlaşmanın sözleşme kısmı, Bulgaristan'daki müftülerin görev ve sorumluluklarını saptamaktadır. Bu sözleşme ile müftülere tanınan haklar genişletilerek Türk okullarının denetimini

\footnotetext{
${ }^{22} \mathrm{Bu}$ anlaşmada İstanbul protokolünün aksine "Türk” kelimesi kullanılmamış "Müslüman” kelimesi tercih edilmiştir. Bu değişiklikle anlaşma sadece Türkleri değil Müslüman olan diğer azınlıkları da kapsamıştır.
} 
de müftülere devretmiştir. Sözü edilen Türk okullarında çalışan Türk öğretmenlerin maaşları devlet bütçesinden karşılanacaktır. Cami ve ibadethanelerin korunması yükümlülüğünü yenileyen bu sözleşme aynı zamanda mezarlıklara da değinerek vakıf olarak kabul etmiştir. Ancak daha sonra da görüleceği üzere Bulgaristan bu sözleşmenin gerekliliklerini yerine getirmeyerek Türk mezarlıklarını yok etmiştir.

Lütem'e göre, Antlaşma kapsamında yapılan bir yenilik olarak dikkat çeken husus, daha önceki antlaşmalarla ülkedeki azınlık grubunun "Türk" olarak tanımlanmasına rağmen, 1913 İstanbul Antlaşması ve Müftüler Sözleşmesi'nde "Müslüman" ifadesinin kullanılmasıdır (Lütem, 2003: 45-46). Bu ifade azınlık sorununu etnik köken dışında dini ayrılıklara da dayandırarak daha kapsamlı bir sunum içermektedir.

\subsubsection{Neuilly Barış Antlaşması}

Birinci Dünya Savaşından mağlup çıkan Bulgaristan, 27 Kasım 1919 tarihinde İtilaf olan devletlerle Neuilly Barış antlaşması imzalayarak bünyesinde barındırdığı azınlıklara ilişkin yasal düzenlemelerini çoklu bir anlaşmayla pekiştirmiştir. Türkiye'nin taraf olmadığı bu antlaşmanın 4. bölümüne göre, Bulgar Devleti din, dil, ırk ve milliyet ayrımı gözetmeyecek, topraklarında yaşayan azınlıklara tam eşitlik sağlayacak, Bulgaristan'daki azınlık grupları dini vecibelerini serbestçe yerine getirme hürriyetine sahip olurlarken; tıpkı bir Bulgar fert hukuksal ve siyasal hakların kullanılması bağlamında ayrıma tabi tutulmayacak, azınlıklar, devlet memurluğuna girebilecekler, istedikleri mesleği veya zanaatı seçebilecekler, ayrıca, azınlıklar eğitim-öğretim kurumları, dini ve sosyal kurumlar açabilecekler, bunları denetleyip yönetebilecekler ve aynı zamanda bu kurum ve kuruluşlarda kendi dillerini özgürce kullanabileceklerdi. Azınlıklar yoğun olarak yaşadığ 1 yerlerde, Bulgar Hükümeti devlet ve belediye bütçelerinden bu azınlık okullarına, dini ve sosyal kurumlara yardım yapacaktır (Şimşir, 1985: 374-375). Bu anlaşma ile azınlıkların sahip olduğu haklar arasında din, dil ve vicdan özgürlüğü güvence altına alınmıştır.

$\mathrm{Bu}$ anlaşmanın en önemli yanı azınlıklarla ilgili kararların değiştirilmesini engelleyen maddedir. Bu maddeye göre Bulgaristan “...hiçbir yasanın, hiçbir yönetmeliğin ve hiçbir resmi kararın bu hükümlere aykırı olmamasını ve bu hükümlere karşı hiçbir yasa, hiçbir yönetmelik ve hiçbir karar ileri sürmemeyi taahhüt” eder (Şimşir, 1985: 263-264).

\subsubsection{Türkiye-Bulgaristan Dostluk Antlaşması}

Cumhuriyetin ilanıyla birlikte Türkiye Cumhuriyeti iletişim halinde bulunduğu ülkelerle dostluk anlaşmaları imzalamıştır. Bu bağlamda 18 Ekim 1925 tarihinde, Ankara'da Türkiye ve Bulgaristan arasında da bir "Dostluk Antlaşması" imzalanır. Bu anlaşmaya göre: "İki Hükümet, azınlıkların korunmasına ilişkin olarak, Neuilly Antlaşması'nda yazılı hükümlerin tümünden Bulgaristan' da oturan Müslüman azınlıklarını ve Lozan Antlaşması'nda yazılı hükümlerin tümünden Türkiye' de oturan Bulgar azınlıklarını yararlandırmayı, karşılıklı olarak yükümlenirler” (Eroğlu, 1988: 142).

Bu anlaşmada göze çarpan unsur Neuilly Barış anlaşmasında taraf olmayan Türkiye'nin de anlaşmayı benimsemiş olmasıdır. Bulgaristan'ın topraklarında barındırdığı azınlıklara tanınmakta olan bütün hak ve özgürlüklerin Türkiye'nin topraklarında barınmakta olan Bulgarlara da tanınması öngörülmektedir.

\subsubsection{Türkiye-Bulgaristan İkamet Sözleşmesi}

Dostluk anlaşmasının imzalandığı tarihte ikamet sözleşmesi de imzalanarak, bu sözleşme ile Türk vatandaşlarına Bulgaristan'da ya da Bulgar vatandaşlarına Türkiye'de yaşama ve yerleşme olanağı sağlanmıştır. Taraflardan birinin yurttaşları öteki ülkeye serbestçe gidip gelebilecek, o ülkede dolaşabileceklerdir. Yapılan anlaşmaya göre Bulgar makamları, Türklerin Türkiye’ye göçlerine 
engel olmayacaklardır. Taşınmaz mallarını göç ettikten sonra iki yıl içinde satabilecekleri hükme bağlanmıştır.

Bu sözleşmenin Türkiye'de yaşayan Bulgarları da kapsadığı görülmektedir. TürkiyeBulgaristan Dostluk anlaşmasıyla Türkiye'de yaşayan Bulgarlara da değinilmiş, konu Bulgaristan'da yaşayan Türkler olmaktan çıkarak karşılıklı bir azınlık sözleşmesi halini almış, bu husus ikamet Sözleşmesiyle pekiştirilmiştir. Ancak bugün de bağlayıcıllğını koruyan sözleşme hükümleri Bulgaristan tarafından sürekli delinmiş ve sözleşmeyi pratikte etkisiz kılmıştır. Her ne kadar çoğu kaynak $^{23}$ bu durumu Komünist Rejimin baskılarına bağlasa da Bulgaristan'ın her yönetim biçiminde bu sözleşmenin ihlalini görmek mümkündür.

\subsubsection{Paris Antlaşması}

İkinci Dünya savaşını bitiren bu antlaşma 10 Şubat 1947 tarihinde Bulgaristan ile Müttefik Devletlerarasında imzalanmış, Türkiye bu anlaşmaya taraf olmamıştır. Halen yürürlükte olan antlaşmanın 2.maddesi Bulgaristan'ın topraklarında yaşayan azınlıkların tamamını kapsamaktadır. Anlaşmada Özbir'in de aktarımıyla: "Bulgaristan, ırk, cinsiyet, dil farkı gözetmeksizin egemenliği altındaki tüm insanların söz, fikir, basın, kültür ve toplantı özgürlükleri dahil tüm temel insan hak ve hürriyetlerden yararlanmasını sağlayacak ve bütün gerekli tedbirleri alacaktır" (Özbir, 1986: 37). ifadesi yer almaktadır. Anlaşmanın kapsamı geniştir ve Bulgaristan'a yönelik olması dikkat çekicidir. Buradaki "tüm temel insan hak ve hürriyetleri" ifadesi önem taşımaktadır, çünkü azınlık hakları bir bütün olarak ele alınmakta ve mevcut bütün anlaşma, sözleşme, protokol ya da bildirgeler kapsamında Bulgaristan'ı sorumlu tutmaktadır.

\subsubsection{Göç Anlaşması}

22 Mart 1968 günü Türkiye ve Bulgaristan dış isleri bakanları arasında imzalanan sınırlı göç antlaşması, 1952 yılına kadar Türkiye'ye göç edip, Türk vatandaşlığına girenlerin bir ve ikinci derece akrabalarının da göçüne izin vermesi nedeniyle, 'Akraba Göçü’ olarak nitelenen göçün anlaşmasıyla düzensiz ve uzun süren bir göç başlamıştır. Lütem'e göre, bu anlaşmanın neticesinde 1978 yılı sonuna kadar 120.000 Türk anavatana göç etmiştir (Lütem, 2000: 81). Bu göçle birlikte ulusal ve uluslararası kamuoyunda çeşitli ikili ya da çok taraflı sözleşmelerle topraklarında barındırdığı azınlıkların hak ve özgürlükler tanıdığını iddia eden Bulgaristan'ın, sözleşmeler ve anlaşmalara bağlı kalmadığını ifade etmek yanlış olmayacaktır.

\subsection{Birleşmiş Milletler Anlaşma ve Sözleşmeleri}

Ulusal ve uluslararası hukuki platformda barışı sağlamaya ve devam ettirmeye yönelik çabalar savaşlar kadar eskidir. Teknolojinin sınırsız olanaklarıyla değişen savaş aygıtlarının yıkıcılığı bu düşüncenin gelişmesine katkıda bulunmuştur. Bu bağlamda Birinci Dünya Savaş1 sonrası Milletler Cemiyeti oluşturulmuş, barışın korunması yönünde çalışmalar yürütmüştür. Hard'a göre bu cemiyet İkinci Dünya Savaşının çıkmasıyla başarısız bir deneme olarak tarihe gömülse de küresel barış ümidini yok edememiştir (Hard, 2002: 130).

İkinci Dünya Savaşı sonrasında kurulan Birleşmiş Milletler Örgütü (BM), "kimilerine göre egemen devletlerin ürettiği anarşinin üstesinden gelmenin tek aracı, kimilerine göre ekonomik ve toplumsal ilişkilerin küreselleşmesine uygun düşecek bir yapılanmadır" (Hardt, 2008: 31). Çok yönlü eleştirilere rağmen varlığını sürdüren Birleşmiş Milletler Örgütünün bağlayıcı sözleşmeleri özellikle azınlık hakları konusunda üye ülkeleri üzerinde hukuki yaptırımlar uygulama gücü nedeniyle önem taşımaktadır.

\footnotetext{
${ }^{23}$ Örnek için bkz. "Halen yürürlükte olduğu belirtilmekle birlikte, Sosyalist Düşüncenin Bulgaristan'daki iktidarı süresince meydana gelen uluslararası hukuk ihlalleriyle 1925 tarihli “Türk-Bulgar İkamet Sözleşmesinin” sağlıklı işleyişine engel olunmuştur”. Türk Kültürü Dergisi, s.250.
} 
Kamil'e göre, Birleşmiş Milletler Kurucu Antlaşması, Jenosit Sözleşmesi, Irk Ayrımını Bütün Şekilleri ile Ortadan Kaldırılmasına İlişkin Sözleşme, Medeni ve Siyasi Haklara İlişsin Sözleşme, Ekonomik, Sosyal ve Kültürel Haklara İlişsin Sözleşme, İnsan Hakları Evrensel Beyannamesi ve Helsinki Nihai Senedi gibi birçok antlaşma ve sözleşmeyle Türk azınlığın hakları uluslararası boyutta teminat altına alınmıştı (Kamil, 1989: 63-80). Bu sözleşmelerde onaylanan haklardan yararlanmak için insan olmak yeterlidir ve hiçbir din, dil, 1rk, etnik grup ayrımı gözetilmeksizin uygulanmaktadır. Bu anlaşmalara bakmak Bulgaristan'ın insan haklarını nasıl çiğnediğini görmek açısından önemlidir.

\subsubsection{Birleşmiş Milletler Örgütü Kurucu Anlaşması}

Bu anlaşma 26 Haziran 1945 tarihinde San Francisco'da imzalanmış ve 110. maddeye uygun olarak 24 Ekim 1945 'de yürürlüğe girmiştir. Türkiye Antlaşmayı Milletlerarası Adalet Divan Statüsüyle birlikte 15 Ağustos 1945'te onaylamıştır. 4801 Sayılı Onay Kanunu 24 Ağustos 1945 gün ve 6902 Sayılı Resmi Gazete de yayınlanmıştır. ${ }^{24}$ Dünyada 189 ülkenin kayıtlı olduğu, evrensel bir karakter taşıyan BM'nin, 1945 kuruluş Antlaşması'nın, Döner'e göre, 1., 13., 55., 56., 62., 68. ve 76. maddelerinde azınlık haklarının korunmasına yönelik vurgular yer almıştır (Döner, 2003: 35-36).

Evrensel bir örgüt olarak kurulan Birleşmiş Milletlerin şemsiyesi altında azınlık hakları daha çok insan hakları alanı içinde ele alınmıştır. Birleşmiş Milletlerin en temel işlevleri, insan haklarının etkili şekilde korunmasını sağlayacak sözleşmeler hazırlanmasını ve bu sözleşmelerin izlenmesi için mekanizmaların kurulmasını sağlamak olmuştur ${ }^{25}$ Anlaşmanın birinci bölümünde amaç ve ilkelerine "Ekonomik, sosyal, kültürel ve insancıl nitelikteki uluslararası sorunları çözmede ve ırk, cinsiyet, dil ya da din ayrımı gözetmeksizin herkesin insan haklarına ve temel özgürlüklerine saygının geliştirilip güçlendirilmesinde uluslararası işbirliğini sağlamak" olarak değinilmektedir. 13. Madde Genel Kurul'un amaçlarını "ekonomik, sosyal, kültürel alanlarda, eğitim ve sağlık alanlarında uluslararası işbirliğini geliş̧irmek ve ırk, cinsiyet, dil ya da din ayrımı gözetmeksizin herkesin insan hakları ile temel özgürlüklerden yararlanmasını kolaylaştırmak için araştırmalar yapılmasına önayak olmak" şeklinde belirtir.

Uluslararasında halkların hak eşitliği ve kendi yazgılarını kendilerinin belirlemesi ilkesine saygı üzerine kurulmuş barışçı ve dostça ilişkiler sağlanması için gerekli istikrar ve refah koşullarını yaratmak üzere Birleşmiş Milletler 55. maddede düzenlemeye gitmiştir. Buna göre, "yaşam düzeylerinin yükseltilmesini, tam istihdamı, ekonomik ve sosyal alanlarda ilerleme ve gelişme koşullarını, ekonomik, sosyal alanlarla sağlık alanındaki uluslararası sorunların ve bunlara bağlı başka sorunların çözümünü, kültür ve eğitim alanlarında uluslararası iş birliğini ve 1rk, cinsiyet, dil ya da din ayrımı gözetmeksizin herkesin insan haklarına ve temel özgürlüklerine bütün dünyada etkin bir biçimde saygı gösterilmesini, kolaylaştıracaktır", vurgusu yapılmıştır. 62. madde Ekonomik ve Sosyal Konsey' in "herkesin insan haklarına ve ana hürriyetlerine ve ana hürriyetlerine bilfiil sayg1 gösterilmesini sağlamak üzere" (Döner, 2003: 36) öneriler getirebileceği, buna paralel olarak 68. madde "insan haklarının gelişmesi" (Döner, 2003: 36) maksadıyla komisyonlar kurabileceği, 76. Madde Vesayet Rejiminin temel amacının "herkesin insan haklarına ve ana hürriyetlerine sayg1 gösterilmesini teşvik etmek ve dünya milletlerinin birbirlerine bağlı oldukları duygusunu geliştirmek" (Döner, 2003: 36) ile ilişkilidir.

\subsubsection{Birleşmiş Milletler Örgütüi Sözleşmeleri}

Örgüt Kurucu Anlaşmasının dışında dünya barışının sağlanmasına yönelik birçok bağlayıcı sözleşmeye de imza atmıştır. Çok yönlü olan bu sözleşmelerden azınlık haklarına değinen sözleşmeleri belirtmekte fayda vardır.

\footnotetext{
${ }^{24}$ Birleşmiş Milletler Anlaşmasının tam metni için bkz. http://www.ombudsman.gov.tr/contents/files/35501Birlesmis-Milletler-Antlasmasi.pdf, (Erişim: 29.07.2013).

${ }^{25} \mathrm{http}$ //insanca.kadikoy.bel.tr./uluslararas__orgutler_ve_ih.html, (Erişim, 25.07.2013).
} 


\subsubsection{Soykırım suçunun önlenmesi ve cezalandırılması sözleşmesi}

1948 yılında Birleşmiş Milletler tarafından azınlıkların korunmasına yönelik ikinci belge olan "Soykırım Suçunun Önlenmesi ve Cezalandırılması Sözleşmesi" ${ }^{26}$ kabul edilmiştir. Sözleşmeyi değerlendiren Kurubaş'a göre: kültürel soykırımdan bahsetmemesi yani azınlıkların "kimlik hakkını" sağlayamamış olması sözleşmeyi eksik ve yetersiz kılmaktadır (Kurubaş, 2004: 49).

\subsubsection{Her türlü ırk ayrımcılığın ortadan kaldırılması sözleşmesi}

7 Mart 1966'da Birleșmiș Milletler tarafindan azınlıkları ilgilendiren "Her Türlü Irk Ayrımcılığın Ortadan Kaldırılması Sözleşmesi" ${ }^{\prime 27}$ kabul edilmiş, 4 Ocak 1969'da yürürlüğe girmiştir. Sözleşmenin 1. maddesi ırk ayrımcılığının tanımını yapar. Buna göre, "siyasal, ekonomik, toplumsal, kültürel ya da kamusal yasamın herhangi bir alanında eşit, insan hakları ve temel özgürlüklere dayalı, yararlanma ya da kullanmayı ortadan kaldırma ya da engelleme amacına dönük ırk, renk, soy, ulusal ya da etnik kökene dayalı herhangi bir ayrımın, dışlamanın, sınırlamanın veya tercihin ırk ayrımcılığı anlamına geleceği” belirtilmektedir. 2. Madde sözleşmeyi kabul eden devletlerin, kişiler, gruplar ve kuruluşlara karsı ırk ayırımcıllğı içeren fiil ve uygulamalardan kaçınmak, ulusal ve yerel tüm resmi kurum ve kuruluşlarının bu yönde hareket etmelerini sağlamak, özel kişi ve örgütleri ırk ayırımı yapmaya teşvik etmekten, desteklemekten kaçınmak ve bu hareketleri engellemek, hukuki mevzuattaki ırkçı maddeleri temizlemek ve bunları yasaklayan kanunlar kabul etmekle yükümlü olduğu vurgulanır. 8. Madde bağımsız on sekiz üyeden oluşan "Irk Ayırımcılığının Ortadan kaldırılmasına Dair Komite'nin kurulmasını öngörürken, 9. Madde ile de taraf devletlerin, iki yılda bir ya da komitenin talebi üzerine, sözleşmenin yürütülmesiyle ilgili olarak alınan tüm yasal, yargısal ve idari tedbirleri içeren raporları sunmakla yükümlü olduğunun bilgisini verir.

Burada üzerinde durulması gereken bir nokta daha vardır ki tam kapsamlı olmasa da azınlık tanımının yerleşmesi açısından söz edilmeyi hak etmektedir. Birleşmiş Milletler İnsan Hakları Komisyonu'nun Ayrımcılığın Önlenmesi ve Azınlıkların Korunması Alt Komisyonu raportörü Francesco Capotorti'nin 1978 yılında hazırladığı raporda önerdiği tanım, daha sonra yapılmış olan tanım denemelerinin temel çerçevesini oluşturmaktadır. Capotorti tarafından hazırlanan raporda azınlık: "Bir devletin nüfusunun geri kalanına göre sayısal olarak az olan, egemen konumda bulunmayan, -o devletin vatandaşı olan, üyeleri nüfusunun geri kalanından farklı etnik, dinsel ya da dilsel özelliklere sahip olan ve kültürlerini, geleneklerini, dinlerini ya da dillerini korumaya yönelik üstü örtülü de olsa bir dayanışma duygusu gösteren grup" ${ }^{28}$ olarak tanımlanır. Bu tanımdaki dikkat çekici nokta, Erdoğan'ın da değindiği üzere, "vatandaşlık" kıstası getirilerek mülteciler ve göçmenlerin dıșlanmasıdır. Farklı özellikler ifadesi nüfusunun geri kalanı homojen olan toplumlara uygulanabilir. Ancak federal devletlerde ve heterojen toplumlarda, yani nüfusun geri kalanı ortak özellik göstermeyen yerlerde bu ayrım bu kadar net ve kolay olmayabilir (Erdoğan, 2000: 241).

Birleşmiş Milletler İnsan Hakları Komisyonu'na bağlı çalışan Ayırımcıllğın Önlenmesi ve Azınlıkların Korunması Alt Komisyonu'nun çalışmaları sonucunda 1966 yılında kabul edilen 1976 y1lında yürürlüğe giren İnsan Hakları Sözleşmeleri ortaya çıkmıştır (Özkan Duvan, 2004: 204).

\footnotetext{
269 Aralık 1948 tarihinde Paris’te toplanan Birleşmiş Milletler Genel Kurulu’nun 260 A (III) sayılı Kararıyla kabul edilip, imza, onay ve katılıma açılmıştır. Sözleşme 13. maddeye uygun olarak 12 Ocak 1951 tarihinde yürürlüğe girmiştir. Türkiye Sözleşmeyi 23 Mart 1950'de onaylamıştır. 5630 Sayılı Onay Kanunu 29 Mart 1950 gün ve 7469 Sayılı Resmi Gazetede yayınlanmıştır.

Tam metin için bkz. http://www.ombudsman.gov.tr/contents/files/32702-Soykirim-Sucunun-Onlenmesine-VeCezalandirilmasina-Dair-Sozlesme.pdf (Erişim: 28.07.2013)

${ }^{27}$ Tam metin için bkz. http://www.ombudsman.gov.tr/contents/files/45408--Her-Turlu-Irk-AyrimciligininOrtadan-Kaldirilmasina-Iliskin-Uluslararasi-Sozlesme.pdf (Erişim, 27.07.2013)

28 UN Economic and Social Council, E/CN.4/Sub.2/1995/27, Commission On Human Rights, U. 01 Ekim 2006, www.un.org (Erişim: 27.07.2013)
} 


\subsubsection{Birleşmiş Milletler İkiz Sözleşmeleri}

Birleşmiş Milletler tarafından hazırlanan ve İkiz Sözleşmeler olarak bilinen Medeni ve Siyasi Haklara İlişkin Uluslararası Sözleşme ile Ekonomik, Sosyal ve Kültürel Haklara İlişkin Uluslararası Birleşmiş Milletler Genel Kurulu tarafından 16 Aralık 1966'da 2200 A(XXI) sayılı kararla kabul edilmiştir. İkiz Sözleşmelerin yürürlüğe girmesi için gereken 35 ülke tarafından onaylanması, 1976 ocak ve mart aylarında tamamlanmış ve sözleşmeler bu tarihte yürürlüğe girmiştir. Bugüne kadar 191 Birleşmiş Milletler üyesinden 148'i bu sözleşmeleri kabul etmiştir. Tüm Avrupa Konseyi üyeler bu sözleşmelerde taraftır.

\subsubsection{Medeni ve siyasal haklarla ilgili sözleşme}

Bu sözleşme bireysel hak ve özgürlüklerin ayrıntılı olarak ele alır. Bulgaristan'ın 21 Eylül 1970 günü taraf olduğu sözleşmede dine ve ırka dayalı nefretin yasaklanması ön görülmüştür ${ }^{29}$.

Sözleşmenin 20. maddesi Ulusal, ırksal ya da dinsel nefretin ayrımcılık, düşmanlık ya da şiddete kışkırtma şeklini alacak biçimde savunulması yasalarla yasaklarken, 24. madde her çocuğun ırk, renk, cinsiyet, dil, din, ulusal ya da toplumsal köken, mülkiyet ya da doğum bakımından hiçbir ayrım gözetilmeksizin, reşit olmayan kişi statüsünün gerektirdiği koruma tedbirlerinin ailesi, toplumu ya da devleti tarafından alınması hakkına sahip olduğunu vurgular. Bununla birlikte 26. Madde herkesin yasalar önünde eşitliğini ve hiçbir ayrım gözetilmeksizin yasalarca eşit derecede korunması şartını öne koyar. Bu bakımdan, yasalar her türlü ayrımı yasaklayacak ve 1rk, renk, cinsiyet, dil, din, siyasal ya da başka fikir, ulusal ya da toplumsal köken, mülkiyet, doğum veya diğer statüler gibi, her bağlamda ayrımcılığa karşı eşit ve etkili korumayı temin edecektir.

\subsubsection{Ekonomik, sosyal ve kültürel haklara ilişkin uluslararası sözleşme}

Sözleşmenin 2. Maddesi bağlamında taraf devletler, sözleşmede belirtilen hakların ırk, renk, cinsiyet, dil, din, siyasal ya da başka fikir, ulusal ya da toplumsal köken, mülkiyet, doğum ya da başka bir statü bakımından herhangi bir ayrım gözetilmeksizin uygulanmasını taahhüt ederler ${ }^{30} . \mathrm{Bu}$ maddeyi pekiştirme niteliğindeki 13. Maddeye göre, herkesin eğitim görme hakkına sahip olduğunu kabul ederler. Taraf Devletler, eğitimin, insanın kişiliğinin ve onur duygusunun tam olarak gelişmesine yönelik olacağı ve insan hakları ile temel özgürlüklere saygıyı güçlendireceği hususunda mutabıktırlar. Taraf Devletler, ayrıca, eğitimin, herkesin özgür bir topluma etkin bir şekilde katılmasını sağlayacağı, tüm uluslar ve tüm ırksal, etnik ve dinsel gruplar arasında anlayış, hoşgörü ve dostluğu geliştireceği ve Birleşmiş Milletlerin barışın korunmasına yönelik faaliyetlerini güçlendireceği hususlarında mutabıktırlar.

\subsubsection{Jenosit'in önlenmesi ve cezalandırılması hakkındaki sözleşme}

Kelime anlamı 'soykırım' olan Jenosit, 9 Aralı 1948 tarihinde Paris'te dine, 1rk veya herhangi bir gerekçeye dayanarak kitle halinde azınlık gruplarının ortadan kaldırılmasını önlemek amacıyla imza edilmiş bir sözleşmedir. İster savaş ister barış zamanında olsun, insanlığa karşı işlenen suçun kabul edilmeyeceğini taahhüt etmektedir (Soysal, 2004: 185).

Sözleşmenin 1. maddesine göre, Sözleşen Taraflar, Jenosit'in ister barış ister savaş zamanında işlenmiş olsun bir Devletler hukuku suçu olduğunu tasdik ederler ve bu suçu önlemeyi ve cezalandırmayı taahhüt ederler ${ }^{31}$. 2. Madde Jenosit'in tanımını yaparak cezaya tabii tutulacak suçları belirler. Buna göre, işbu Sözleşmede, jenosit, millî, etnik, ırkî veya dinî bir grubu kısmen veya tamamen imha etmek maksadıyla aşağıdaki fiillerden herhangi birinin irtikâp olunması demektir. Grup azalarının katli, grup azalarının bedenî ve aklî melekelerinin ciddi surette haleldar

\footnotetext{
${ }^{29}$ Tam metin için bkz. http://www.tbmm.gov.tr/kanunlar/k4868.html (Erişim: 22.07.2013).

${ }^{30}$ Tam metin için bkz. http://www.tbmm.gov.tr/komisyon/insanhaklari/pdf01/83-93.pdf (Erişim: 22.07.2013).

${ }^{31}$ Tam metin için bkz. http://www.unicankara.org.tr/doc_pdf/jenosit.pdf (Erişim: 25.07.2013).
} 
edilmesi, grubun, bedenî varlığının kısmen veya tamamen imhasına müncer olacak hayat şartlarına kasten tabi tutulması, grup içinde doğumları sekteye uğratacak tedbirler alınması, bir grup çocuklarının diğer bir gruba zorla nakledilmesi cezalandırılmaya sebep olarak sunulmaktadır.

Bunun yanında 5. Madde Sözleşen Taraflar, sözleşmenin uygulanması üzere kendi anayasalarına uygun olarak gerekli tedbirleri almayı, özellikle jenosit veya 3. maddede adı geçen fiilleri işlemekten suçlu şahıslara gerekli cezaları vermeyi taahhüt ederler.

\subsubsection{Ulusal veya Etnik, Dinsel veya Dilsel Azınlıklara Mensup Olan Kişilerin Haklarına Dair Bildiri}

Birleşmiş Milletler Genel Kurulu'nun 20 Aralık 1993 tarihli ve 47/135 sayılı Kararıyla ilan edilmiş olan bildiri adından da belli olduğu üzere, Bildiri Birleşmiş Milletlerin temel amaçlarından birinin, Birleşmiş Milletler Şartında ilan edildiği üzere ırk, cinsiyet, dil veya din gibi bir ayrımcılığa tabi tutmaksızın herkesin insan haklarına ve temel özgürlüklerine saygıyı teşvik etme ve geliştirme olduğunu ve temel insan haklarına, insanlık onuruna ve insanın değerine, erkekler ve kadınlar ile küçük-büyük bütün ulusların eşit haklara sahip olduklarına dair inancını yeniden teyit eder. ${ }^{32}$ Bildiri bu çerçevede, 1. maddesinde azınlıkların korunmasına değinerek 2. maddede hakların çerçevesini belirler. Buna göre, ulusal veya etnik, dinsel veya dilsel azınlıklara mensup kişiler ${ }^{33}$, özel veya kamusal yaşamda hiçbir müdahaleye veya hiçbir ayrımcıllı̆g maruz kalmadan ve serbestçe kendi kültürlerini yaşama, kendi dinlerinde ibadet etme ve uygulamada bulunma ve kendi dillerini kullanma hakkına sahiptir. Bununla birlikte azınlıklara mensup olan kişiler kültürel, dinsel, sosyal, ekonomik ve kamusal yaşama etkili bir biçimde katılma hakkına sahiptir. Azınlıklara mensup olan kişiler ulusal düzeyde ve uygun olduğu takdirde, mensubu oldukları azınlıklarla veya üzerinde yaşadıkları bölgelerle ilgili olarak bölgesel düzeyde verilen kararlara ulusal mevzuata aykırı olmayacak bir tarzda etkili bir biçimde katılma hakkına sahiptir. Azınlıklara mensup olan kişiler kendi örgütlerini kurma ve sürdürme hakkına sahiptir. Azınlıklara mensup olan kişiler hiçbir ayrımcılığa maruz kalmadan, kendi grubunun diğer üyeleriyle ve başka azınlıklara mensup kişilerle ve ayrıca hudut komşusu diğer Devletlerin ulusal veya etnik, dinsel veya dilsel başlarla bağlı oldukları vatandaşlarıyla serbest ve barışçıl ilişkiler kurma ve bu ilişkileri sürdürme hakkına sahiptir.

\subsubsection{Din veya İnanca Dayanan Her Türlü Hoşgörüsüzlüğün ve Ayrımcılığı Tasfiye Edilmesine Dair Bildiri}

Birleşmiş Milletler Genel Kurulu'nun 25 Kasım 1981 tarihli ve 36/55 sayılı Kararıyla ilan edilen bildiri din veya inanç, inancını açılayan bir kimsenin yaşam anlayışının temel unsurlardan biri olduğunu ve bu din veya inanç özgürlüğüne bütünüyle sayg1 gösterilmesi ve güvence altına alınması gerektiğini dikkate aldığını vurgulayarak bu bağlamda, "Herkes düşünce, vicdan ve din özgürlüğ̈ hakkına sahiptir. ${ }^{34} \mathrm{Bu}$ hak, bir dine veya dilediği bir inanca sahip olma ve dinini veya inancını kendi başına veya başkaları ile birlikte toplu olarak ve aleni veya gizli bir biçimde ibadet etme, gereklerine uyma, uygulama ve öğretme yoluyla açışa vurma özgürlüğünü de içerir. Hiç kimse bir dine veya dilediği inancına sahip olma özgürlüğünü zedeleyecek bir zorlamaya maruz bırakılamaz." Bildiri aynı zamanda bu konuda bazı sınırlandırmalar koyar ve 1. maddede bunu açıç̧a dile getirir. "Bir kimsenin dinini veya inancını açığa vurma özgürlügü, sadece hukuken öngörülen ve kamu güvenliğini, kamu düzenini, sağlığı, ahlakı veya başkalarının temel hak ve özgürlüklerini korumak için gerekli olduğu ölçüde sınırlamalara tabi tutulabilir." 3. madde din ve ayrımcılığın tanımı yapılırken, 2. maddede bu ayrımcılık kesin bir dille yasaklanır, bunun yanında 4 . madde üye devletlere bu uygulama pratikleri içerisinde uygulama zorunluluğu koyar.

32 Tam metin için bkz. http://www.ombudsman.gov.tr/contents/files/716b2--Ulusal-veya-Etnik,-Dinsel-veyaDilsel-Azinliklara-Mensup-Olan-Kisilerin-Haklarina-Dair-Bildiri.pdf(Erişim:21.07.2013)

${ }^{33}$ Bildiride "azınlıklar" yerine "azınlıklara mensup olan kişiler" ifadesi kullanılmaktadır.

34 Tam metin için bkz. http://www.ombudsman.gov.tr/contents/files/750B3--Din-veya-Inanca-Dayanan-HerTurlu-Hosgorusuzlugun-ve-Ayrimciligin-Tasfiye-Edilmesine-Dair-Bildiri.pdf (Erişim: 21.07.2013) 
Bildiride 6. Madde önem taşımaktadır. Bu madde ile düşünce, vicdan veya inanç özgürlügünün içeriği belirlenir. Buna göre, din veya inanç ile bağlantılı olarak, ibadet etme veya toplanma ve bu amaç için gerekli yerleri kurma ve kullanma, gerekli vakıf veya insancıl amaçlı kurumlar kurma ve bunları işletme, bir dinin veya inancın törenlerine veya geleneklerine ilişkin gerekli araçları ve materyalleri yeterli ölçüde yapma, alma ve kullanma, bu alanla ilgili yayımları yazma, yayınlama ve dağıtma, bir din veya inancın öğretimini, bu amaçlar için uygun yerlerde yapma; bireylerden ve kurumlardan gönüllü mali yardım vermelerini isteme ve alma, bir dinin veya inancın gerekleri ve standartları bakımından uygun olan liderleri yetiştirme, atama, seçme ve yerini alacak olanı belirleme, bir kimsenin dininin veya inancının kurallarına uygun olarak dinlenme günlerine ve bayram tatillerine ve törenlerine uygun davranma, ulusal ve uluslararası düzeyde, din ve inanç konularında bireyler ve topluluklarla iletişim kurma ve sürdürme özgürlüklerini de içerir.

\section{4. İnsan Hakları Evrensel Bildirgesi}

İnsan Hakları Evrensel Bildirgesi'nde ${ }^{35}$ azınlık haklarına doğrudan değinilmemekle birlikte, bu konu ayrımcilığın engellenmesi ilkesi içeriğine eklenmiştir. Bildirinin 2. maddesine göre:" Herkes, 1rk, renk, cinsiyet, dil, din, siyasal veya başka bir görüş, ulusal veya sosyal köken, mülkiyet, doğuş veya herhangi başka bir ayrım gözetmeksizin bu Bildirge ile ilan olunan bütün haklardan ve bütün özgürlüklerden yararlanabilir. Ayrıca ister bağımsız olsun ister vesayet altında veya özerk olmayan ya da başka bir egemenlik kısıtlamasına bağlı ülke yurttaşı olsun, bir kimse hakkında, uyruğunda bulunduğu devlet veya ülkenin siyasal, hukuksal veya uluslararası statüsü bakımından hiçbir ayrım gözetilmeyecektir.” Bununla birlikte yaşamak, özgürlük ve kişi güvenliği herkesin hakkıdır. 26. ve 2. Maddeler de azınlık haklarını ilgilendiren kültürel haklara yer verir. Buna göre, eğitim, bütün uluslar, ırklar ve dinsel topluluklar arasında anlayış, hoşgörü ve dostluğu özendirmelidir, herkes toplumun kültürel yaşamına serbestçe katılma, güzel sanatlardan yararlanma, bilimsel gelişmeye katılma ve bundan yararlanma hakkına sahiptir, herkesin yaratıcısı olduğu bilim, edebiyat ve sanat ürünlerinden doğan maddi ve manevi çıkarlarının korunmasına hakkı vardır. Bununla birlikte 28. Maddeye göre, herkesin bu Bildirgede öngörülen hak ve özgürlüklerin gerçekleşeceği bir toplumsal ve uluslararası düzene hakkı vardır.

\subsection{Avrupa Güvenlik ve İş Birliği Konferansı Nihai Senedi (Helsinki Deklarasyonu)}

Amerika ile Sovyetler Birliği arasında yedi yıllık SALT-II görüşmeleri devam ederken, Avrupa'da, yine Amerika ile Sovyet Rusya'nın da dâhil olduğu; yumuşama girişimleri başlar. Bu gelişmeler, Avrupa'da bir güvenlik ve iş birliği sisteminin kurulması ile karşılıklı ve dengeli kuvvet indirimi müzakereleri düşüncesini geliştirir. Bu değişim, 1 Ağustos 1975 de 35 ülke tarafından imzalanan Nihai Senet veya Helsinki Deklarasyonu adını alan belgedir. ${ }^{36}$

\footnotetext{
${ }^{35}$ Birleşmiş Milletler Genel Kurulu'nun 10 Aralık 1948 tarih ve 217 A(III) sayılı Kararıyla ilan edilmiştir. 6 Nisan 1949 tarih ve 9119 Sayılı Bakanlar Kurulu ile "İnsan Hakları Evrensel Beyannamesi'nin Resmi Gazete ile yayınlanması yayımdan sonra okullarda ve diğer eğitim müesseselerinde okutulması ve yorumlanması ve bu Beyanname hakkında radyo ve gazetelerde münasip neşriyatta bulunulması" kararlaştırılmıştır. Bakanlar Kurulu Kararı 27 Mayıs 1949 tarih ve 7217 Sayılı Resmi Gazetede yayınlanmıştır. Tam metin için bkz. http://www.ombudsman.gov.tr/contents/files/688B1-Insan-Haklari-Evrensel-Beyannamesi.pdf

(Erişim: 28.07.2013).

363 Temmuz 1973'te Helsinki'de açılan ve 18 Eylül 1973'ten 21 Temmuz 1985'e kadar Cenevre'de süregelen Avrupa Güvenlik ve İşbirliği Konferansı, 1 Ağustos 1975'te Helsinki'de toplanan Amerika Birleşik Devletleri, Avusturya, Birleşik Krallık, Belçika, Bulgaristan, Çekoslovakya, Danimarka, Demokratik Almanya, Federal Almanya, Finlandiya, Fransa, Hollanda, İrlanda, İspanya, İsveç, İsviçre, İtalya, İzlanda, Kanada, Kıbrıs, Lihtenştayn, Lüksemburg, Macaristan, Malta, Monako, Norveç, Polonya, Portekiz, Romanya, San Marino, Sovyetler Birliği, Türkiye, Vatikan, Yugoslavya ve Yunanistan Yüksek Temsilcileri tarafından sonuçlandırılmıştır. Tam metin için Bkz. http://www.ombudsman.gov.tr/contents/files/374d2--Avrupa-Guvenlik-ve-Isbirligi-Konferansi-Sonuc-Bildirgesi(Helsinki-Belgesi).pdf (Erişim 27.07.2013).
} 
Yedi maddeden oluşan deklarasyonun 7. Maddesi azınlık hak ve özgürlük çerçevesini belirler. Düşünce, vicdan, din ya da inanç özgürlüğü dahil insan haklarına ve temel özgürlüklere saygı başlığını taşıyan bu maddeye göre, katılan devletler ırk, cinsiyet, dil ya da din ayrımı gözetmeksizin herkes için düşünce, vicdan, din ya da inanç özgürlüğü dahil, insan haklarına ve temel özgürlüklere saygı gösterir. Her biri insan kişiliğinin niteliğindeki onurdan doğan ve bu kişiliğin özgür ve tam gelişmesi için temel olan kişisel, siyasal, ekonomik, toplumsal, kültürel ve öteki hakların etkin biçimde kullanılmasını güdüleyerek özendirir. Bu çerçeve içinde katılan devletler, bireyin, tek başın ya da başkalarıyla birlikte kendi vicdanı uyarınca din ya da inancını açıklama ve uygulama özgürlügünü tanır ve ona saygı gösterir. Ülkelerinde ulusal azınlıklar bulunan katılan Devletler, bu azınlıklardan olan kişilerin yasa önünde eşitlik hakkına saygı göstererek onlara insan hakları ve temel özgürlüklerden gerçekten yararlanmaları için tam firsat tanır ve bu amaçla bu alandaki yasal çıkarlarını korur. Katılan Devletler, insan hakları ve temel özgürlüklere saygının, kendileri ve tüm Devletlerarasında dostça ilişkiler ve iş birliğinin gelişmesini sağlamak için gerekli barış, adalet ve refahın temeli olduğunu görüşüyle bu hak ve özgürlüklerin evrensel önemini tanır. Karşı1ıklı ilişkilerinde insan hakları ve temel özgürlüklere sürekli saygı göstererek, Birleşmiş Milletlerle iş birliği dâhil, bu hak ve özgürlüklere evrensel ve etkin olarak saygı gösterilmesini özendirmek için birlikte ve ayrı ayrı çaba gösterir. Bireyin bu alanda bilgili olmak hakkını ve hak ve ödevlerine göre davranmasını kabul eder. Katılan Devletler, insan hakları ve temel özgürlükler alanında Birleşmiş Milletler Antlaşmasının amaç ve ilkelerine ve İnsan Hakları Evrensel Bildirgesine uygun olarak davranır. Bu alanda, ötekilerin yanı sıra bağlı olabilecekleri Uluslararası insan Hakları Sözleşmeleri dahil Uluslararası belgeler ve sözleşmelerde konmuş olan yükümlülüklerini de yerine getirir.

Dikkat edilirse deklarasyon özellikle dini ve kültürel özgürlüklere değinmekte, dini gerekliliklerin yerine getirilmesini teşvik etmekte, kültürel çeşitliliği yansıtarak farklılıkların zenginliğini vurgulamakta, bu hak ve özgürlüklere evrensel ve etkin olarak sayg1 gösterilmesini özendirmektedir. Ancak Şimşek'in de belirttiği üzere, Sovyet Rusya'nın dahi altına imza koyduğu böylesi bir sözleşmenin diğer imzacısı Bulgaristan, kısa süreli sözlerini tutamayarak, toprakları üzerinde yaşayan Türk azınlığa karşı soykırım faaliyetlerine devam etmiştir.

\subsection{Avrupa Konseyi}

Avrupa Konseyi'nin Statüsüne Dair Sözleşme 5 Mayıs 1949 tarihinde Londra'da imzaya açılmış ve 42. maddeye uygun olarak 3 Ağustos 1949 tarihinde yürürlüğe girmiştir. Türkiye Sözleşmeye 13 Nisan 1950 tarihinde katılmış ve 12 Aralık 1949 tarihinde onaylamıştır. 5456-Sayılı Onay Kanunu 17 Aralık 1949 gün ve 7382 Sayılı Resmi Gazetede yayınlanmıştır. ${ }^{37}$ Konseye 07 Mayıs 1992 tarihinde dahil olan Bulgaristan 6 temsilci bulundurma yetkisine sahiptir.

Konseyde adalet ve uluslararası iş birliğine dayalı olan barışı sürdürmenin insanlık toplumu ve uygarlığının korunması için yaşamsal bir önem taşıdığına değinilerek, halklarının ortak mirası olan ve tüm gerçek demokrasilerin temelindeki bireysel özgürlük, siyasal özgürlük ve hukuk düzeni ilkelerinin gerçek kaynağını oluşturan manevi ve ahlaki değerlere derin bağllıklarına vurgu yapılmaktadır.

Görüldüğü üzere Bulgaristan ülkesinde barındırdığı azınlık haklarına ilişkin kendi anayasası çerçevesinde birçok ikili ya da çoklu anlaşmaya imza atmıştır. Ancak uygulanan asimilasyon politikası düşünüldüğünde hiçbir hukuki dayanağı olmayan bir baskı rejimi görülmekte dolayısıyla anlaşmaların tek taraflı olarak sürekli Bulgaristan tarafından çiğnendiği gözlemlenmektedir.

\footnotetext{
${ }^{37}$ Tam metin için bkz. http://www.ombudsman.gov.tr/contents/files/771a1--Avrupa-Konseyi-Statusu.pdf (Erişim: 27.07.2013).
} 


\section{Sonuç}

1989 y1lı dünya tarihinde kendine önemli bir yer edinmektedir. Batı'da yıllarca "Utanç Duvarı" (Schandmauer) olarak da anılan ve Batı Berlin'i abluka altına alan bu betondan sınırdan oluşan Berlin Duvarı'nın yıkılması 1989 yılı denildiğinde ilk akla gelen tarihi yapı olarak algılansa da çok farklı siyasal gelişmelerin de odağını oluşturmaktadır. 1989 yılı iki kutuptan biri olan Rusya'nın Gorbaçov'la başlayan Perestroyka (yeniden yapılandırma) ve Glasnost (açıklık) serüvenini de sonlandırmaktadır. Gorbaçov perestroykayı anlatırken: "Perestroyka, sosyalizmin yenileştirilmesi için uygulamaya koyulmuş bir politikadır. Daha fazla demokrasi, daha fazla özgürlük yolunda atılmış bir adımdır. Perestroykanın bir diğer amacı ise, sosyalizme ait olmayan olgulardan vazgeçmektir." cümlesini kurmuş olsa da bu politik yaklaşım 1989 yılında Rusya'da farklı bir siyasal sisteme geçişin de ayağını oluşturmaktadır. Aynı zamanda bu açılama sosyalizmin iflasının diplomatik dil ile ifadesi niteliği taşımaktadır. Temelde Perestroyka ve Glasnost politikalar bazı ekonomik, sosyal ve siyasal hakların verilmesi ve bu konularda daha esnek bir yönetim anlayışının benimsenmesi prensibini içeriyordu. Ancak bu politikalar zaten parçalanmakta olan birliği bir arada tutmaya yetmedi.

Sovyetler Birliği’nin Doğu Avrupa'yı kendine bağlı tutmak için yapmış olduğu sermaye aktarımının tükenme noktasına gelmesi ve bu ülkelerin de ekonomik politika anlamında verimsiz tercihlerde bulunmaları, yaşam standartları düşürmüş ve yaşanan çöküşün en önemli etmenlerinden biri olmuştur. Ayrıca, Batı toplumlarındaki bilişim teknolojisine ayak uyduramama ve bilginin sosyalist devletlerce denetim altına alınamaması Doğu Avrupa toplumlarının bu gelişmelerden haberdar olmasına ve etkilenmesine neden olmuştur. Bu etkileşim sistem açısından yıkıcı sonuçlar doğurmuştur. Bir diğer etmen ise çevresel kirliliğin artması üzerine başlayan eleştirilerin zamanla çevreci bir muhalif harekete dönüşmesidir. Öyle ki, Bulgaristan özelinde sisteme karşı ilk halk gösterisi çağrısı, ülkedeki çevreci hareket olan Ecoglasnost’tan gelmiştir. Bütün bu dinamiklerin yaşandığı bölgede, siyasî sistemin dayandığı ideolojik temelin ve yönetici sınıfın meşruluk bunalımına girmesi sosyalist yönetimlerin art arda çökmesine yol açmıştır (Palmer, s.90-91).

25 Aralı 1991 tarihinde SSCB Devlet Başkanı Mihail Gorbaçov'un istifa etmesinin ardından Sovyetler Birliği'ni teşkil eden cumhuriyetlerin bağımsızlığını kazanmalarıyla Sovyet Sosyalist Cumhuriyetler Birliği dağılmış kapitalist sisteme geçilmiştir. Ancak SSCB'nin durumu çok önceden Balkan ve Avrupa devletlerini etkilemiştir. Polonya, Doğu Almanya, Çekoslovakya, Bulgaristan, Romanya ve Macaristan Komünist yönetimi 1990 yılında terk ederek serbest piyasa ekonomisine geçiş yapmıştır.

Konumuz olan Bulgaristan açısından durum biraz farklıdır. Bilinen ve değinilen sebeplerin yanında, SSCB ile bilinen yakınlığının yanında özellikle 1985 yılında şiddetle başlayan ve Jivkov yönetiminin planlı asimilasyon politikasına maruz kalan Bulgaristan'da yaşayan Türklerin zorunlu tehciri Bulgar ekonomisinin çıkmaza girmesine neden olmuştur. Bunun en önemli sebebi bir tarım ülkesi olan Bulgaristan'da tarım işlerini çoğunlukla Türklerin üstlenmiş olmasından kaynaklanmaktaydı. Bu nedenle Bulgaristan'da yaşayan Türklere karşı yürütülen asimilasyon politikası başarısız olurken bu durum aynı zamanda Bulgaristan'ın ekonomik bunalım yaşamasına ve bunun sonucunda, mevcut siyasal rejimin terk edilerek serbest piyasa ekonomisine geçişe yol açmıştır.

1989 y1lı Bulgar tarihine olmasa da dünya tarihine "Bulgaristan'da Türklere karş1 asimilasyonun, büyük tehcirin, insanlık ayıbının yaşandığı, ulusal ya da uluslararası mevcut bütün insan haklarının çiğnendiği yıl” olarak kabul edilebilir. Bulgaristan'ın bağımsızlı̆̆ını kazandığı günden itibaren Bulgaristan'daki Türklerin (1877-78) Osmanlı Rus savaşı sonrasında göç ettirilme yoluyla azınlık durumuna düşürülmesinin ardından Bulgaristan'ın Bulgaristan'da yaşayan Türklere karşı politikası zaman zaman değişiklik gösterse de temelinde barışçıl olduğunu söylemek yanlış olacaktır. İlk dönemlerinde Bulgaristan'ın iç hukukunda imza attığı uluslararası anlaşmalarda azınlık 
kelimesini kullanmayarak Türklere yönelik maddeleri kabul etmesi olumlu bir gelişme olarak düşünülse de zaman içerisinde "Türk" kelimesini kaldırarak yerine "ulusal azınlık" tarifini koyması izlediği yolun açık bir ifadesini oluşturmaktadır. Jivkov'un iktidara gelmesiyle başlayan süreçte tek bir Bulgar-Slav 1rkı yaratma hayaliyle izlenen politik dönüşüm açıkça görülmektedir. Her firsatta kullanılan "Bulgaristan Müslümanları" ifadesi durumun ehemmiyetini gözler önüne sermektedir.

Ad değiştirme, dini ibadetlerin yerine getirilmesini yasaklama, sünnet ve dini nikah gibi ritüellere son verme, şalvarın giyilmesine müdahale etme ve zaman içinde Türkçe konuşulması hatta Türk müziğini yasaklama gibi yaptırımların direnişle karşılanması ve cezaların fayda etmemesi uygulanan politikanın sertleşmesine ve ölümlere sebep olmuştur. Bu aşamada dünya kamuoyuna etnik şiddetin varlığını reddederek haklı gerekçeler sunmak için basın kullanılmış her türlü propagandaya başvurulmuştur. Bulgar basını etnik oluşum olarak Bulgaristan'da Türk varlığını reddederken onları Bulgar Müslümanlar olarak adlandırmış, Türkiye'yi karalama kampanyaları başlatmıştır. Bulgaristan'da yaşayan Türkleri kabul eden Türkiye her firsatta Bulgaristan'ın iç işlerine karışmakla suçlanmış ve her aşamada yerilmiştir.

Ulusal ve uluslararası arenada azınlıkların hak ve özgürlüklerinin güvence altına alınması ve asimile olmalarının engellenmesi için hukuki arenada Bulgaristan ikili ya da çoklu pek çok anlaşmaya imza atmış ve uluslararası kamuoyunda azınlıklara karşı koruyucu bir tutum sergilediği izlenimini uyandırmıştır. Ancak tarihe bakıldığında sık sık ve sürekli olarak meydana gelen göç adı altındaki tehcirler durumun çok da hukuki çerçevede değerlendirilemeyeceğini göstermektedir. Bulgaristan'ın, ülkesinde yaşayan Türklere uyguladığı asimilasyon ve tehcir politikalarını hukuki bağlama oturtmak mümkün değildir. Hiçbir dayanağı olmayan baskı rejimi çok açık görülmekte, Bulgaristan'ın anlaşmaları kendi lehine ihlali gözlemlenmektedir.

Bulgaristan'ın asimilasyon politikasını çok sistematik olarak uygulaması ve yönetmesi o dönemde yönetildiği Komünist rejime bağlamak mümkündür. Siyasal sitemin sansür ve bask1 üzerine konumlanmış yapısı tehciri kolaylaştırmakta ve mevcut yönetim için paravan oluşturarak dış müdahalelere izin vermemektedir. Siyasal sistemin değişimiyle birlikte ülkedeki azınlıklara yönelik politikalardaki değişim ve Avrupa Birliği sürecinde Bulgaristan'ın girdiği yenilenme süreci başka bir çalışma konusu olarak düşünülebilir.

\section{Kaynakça}

Ağanoğlu, H. Y. (2001). Osmanlı'dan Cumhuriyete Balkanlar'in Makus Talihi: Göç. Kum Saati Tarih Dizisi. İstanbul.

Akgönül, S. (2016). Türkiye Rumları: Ulus-Devlet Çağından Küreselleşme Çağına Bir Azınlı̆̆ın Yok Oluş Süreci. İletişim Yayınları. İstanbul.

Akgönül, S. (2011). Azınlık. Türk Bağlamında Azınlık Kavramına Çapraz Bakışlar. BGST Yayınları. İstanbul. 2011.

Alp, İ. (2008). Pomak Türkleri (Kumanlar-Kıpçaklar). Trakya Üniversitesi Sosyal Bilimler Enstitüsü Yayınlar1. Edirne.

Çavuşoğlu, N. (2001). Uluslararası İnsan Hakları Hukukunda Azınlık Hakları. Su Yayınları. İstanbul.

Dechenes, J. (1985). Proposal Concerning A Definition Of The Term "Minority”. Un Doc. E/Cn, 4.

Dayığlu, A. (2002). Bulgaristan'daki Müslüman-Türk Azınlı̆̆ (1878-2000). Yayınlanmamış Doktora Tezi. Ankara Üniversitesi. Sosyal Bilimler Enstitüsü. Ankara. 
Döner, A. (2003). İnsan Haklarının Uluslararası Alanda Korunması ve Avrupa Sistemi. Seçkin Yayınc1lik. Ankara.

Erdoğan, B. (2000). Uluslararası Hukukta Azınlık Haklarının Korunması, BM ve Avrupa Sistemlerinin İncelenmesi. Türkiye'de İnsan Hakları, TODAİE Yayın No: 301, Ankara.

Erim, N. (1953). Devletlerarası Hukuku ve Siyasi Tarih Metinleri Cilt no. 1. Ankara Üniversitesi Hukuk Fakültesi Yayınları. Ankara.

Eroğlu, E. (1988). Yenilenme Bilinci. Nehir Yayınları. Ankara.

Eryılmaz, B. (1990). Osmanlı Devleti’nde Gayrimüslim Tebaanın Yönetimi. Doğan Ofse., İstanbul.

Goffman, E. S. (2009). Notes On The Management of Spoiled Identity. Simon and Schuster.

Gömeç, S. (1999). Türk Cumhuriyetleri ve Toplulukları Tarihi. Akçă̆ Yayınları. Ankara.

Gündüz, A. (1985). İki Taraflı ve Çok Taraflı Milletlerarası Anlaşmalar Işı̆̆ında Bulgaristan Türklerinin Durumu. Bilim, Kültür ve Sanatta Gerçek. Cilt no.1. Sayı no.1. Ekim.

Hakov, C. (2002). 1913 Yılında İstanbul'da Imzalanan Bulgar-Türk Antlaşması ve Bulgaristan TürkMüslüman Nüfusun Haklart. XIII. Türk Tarih Kongresi. Ankara, 4-8 Ekim 1999 Kongreye Sunulan Bildiriler III: Cilt no. 1. TTK Basımevi.

Halaçoğlu, A. (2002). Balkanlar'dan Anadolu'ya Yönelik Göçler. Yeni Türkiye Yayınları. Ankara.

Hard, L. (2002). II. Dünya Savaşı Tarihi. Çev. Bağrıaçık, K. Yapı Kredi Yayınları. İstanbul.

Hardt, M. ve Negri, A. (2008). İmparatorluk. Ayrıntı Yayınları, İstanbul.

Horata, O. (2003). Kuzey ve Batı Türklüğ̈̈nün Kesişme Noktasında Küçük Bir Türk Topluluğu: Romanya Türkleri. Editör.Türbedar, E. Balkan Türkleri Balkanlarda Türk Varlığı. ASAM Yayınları. Ankara.

Jelavich, B. (2009). Balkan Tarihi 2. Küre Yayınları. İstanbul.

Kamil, İ. (1989). Bulgaristan'daki Türklerin Statüsü. Türk Dünyası Araştırmaları Vakfı. İstanbul.

Kekioğlu, O. (1985). Kültür Eserleri Dizisi, Bulgaristan'da Türkler. Kültür ve Turizm Bakanlığ 1 Yayınlar1: 642. 48. Ankara.

Konukman, E. (1990). Tarihi Belgeler Işığında Büyük Göç ve Anavatan: Nedenleri, Boyutları ve Sonuçları. Ankara.

Korkud, R. (1986). Bulgar Yönetimi ve Tarihi Yalan. Türkiye Fikir Ajansı. Ankara.

Koyuncu, A. (2005). Balkanlarda Dönüşüm, Milli Devletler ve Osmanlı Mirasının Tasfiyesi: Bulgaristan Örneği (1878-1913). Yayımlanmamış Doktora Tezi. Ankara.

Kurubaş, E. (2004). Asimilasyondan Tanınmaya Uluslararası Alanda Azınlık Sorunları ve Avrupa Yaklaşımı. Asil Yayın Dağıtım. Sayı: 9. Ankara.

Küçük, C. (1986). Osmanl Millet Sistemi ve Tanzimat, Tanzimat'tan Cumhuriyete Türkiye Ansiklopedisi. İletişim Yayınları. İstanbul.

Larrain, G. (1995). İdeoloji ve Kültürel Kimlik. Çev. N. Domaniç. Sarmal Yayınevi. İstanbul.

Memişoğlu, H. (1999). Balkanlar'da Pomak Türkleri. Türk Dünyası Araştırma Vakfı Yayını. İstanbul.

Lütem, E. Ö. (2000). Türk-Bulgar ilişkileri 1983-1989. ASAM Yayınları. Ankara. 
Lütem, E. Ö. (2003). Tarihsel Süreç içinde Bulgaristan Türklerinin Haklarl, Derleyen: TÜRBEDAR, Erhan. "Balkan Türkleri/Balkanlar'da Türk Varlığı". ASAM Yayınları. Ankara.

Oğuz, S. (1987). Osmanlı Vilayet İdaresi ve Doğu Rumeli Vilayeti. Cem Ofset Matbaası. İstanbul.

Oran, B. (2001). Küreselleşme ve Azınlıklar. İmaj Yayınevi, Ankara.

Özkan Duvan, A. (2004). Avrupa Birliği ve Azınlık Hakları. Avrasya Dosyası Avrupa Birliği Türkiye İlişkileri, Cilt no. 10, Sayı no. 2.

Özbir, K. (1986). Bulgar Yönetimi Gerçeği Gizleyemez. Başkent Gazetecilik, İstanbul.

Özgür, N. (1999). Etnik Sorunların Çözümünde Hak ve Özgürlükler Hareketi. Der Yayınları. İstanbul.

Öztürk, S. (2006). Türk Sinemasında İlk Sansür Tartışmaları ve Yeni Belgeler. Galatasaray İletişim. İstanbul. Haziran.

Palmer, T. (2004). Sosyalizm Doğu Avrupa'da Neden Çöktü, Çev. Yılmaz, Z. Liberal Düşünce. Sayı: 33.

Sander, O. (2001). Siyasi Tarih İlk Çağlardan 1918'e. İmge Kitabevi. Ankara.

Soysal, İ. (2004). Türkiye’nin Uluslararası Siyasal Bağıtları (1945-1990). Türk Tarih Kurumu Basımevi. Ankara, Cilt no. 2.

Stamboliyski, A. (1979). İzbrani Proizvedeniya, Yayına Hazırlayan. DİMOV. Nenço, İzdatelstvo Na BZNS. Sofya.

Şimşir, N. B. (1985). Bulgaristan Türk Azınlığının Ahdi Durumu. Türk Kültürü. Sayı no. 264, 24 Nisan.

Şimşir, N. B. (1986). Bulgaristan Türkleri (1878- 1985). Bilgi Yayınevi. İstanbul.

Şimşir, N. B. (1989). Rumeli'den Türk Göçleri. Türk Tarih Kurumu Yayınları. Ankara.

Şimşir, N. B. (1992). Bulgaristan Türkleri ve Gö̧̧ Sorunu, Bulgaristan'da Türk Varlı̆ğ. Türk Tarih Kurumu Yayınları. Ankara.

Şimşek, H. (1999). Türk-Bulgar İlişkileri ve Göç. Harp Akademileri Basımevi. İstanbul.

Tajfel, H. H. (1981). Groups and Social Categories: Studies In Social Psychology. Cup Archive.

Toğrol, B. (1991). DIRENIŞ- Bulgaristan Türklerinin 114 Yıllık Onur Mücadelesinin Karşılaştırılmalı Psikolojik İncelenmesi. Boğaziçi Ü. Matbaası. İstanbul.

Toğrol, B. (1989). 112 Yıllık Göç (1878- 1989). Boğaziçi Üniversitesi Matbaası. İstanbul.

Turan, Ö. (1995). Bulgaristan Türklerinin Bugünkü Durumu. Yeni Türkiye. Sayı no. 3. Ankara.

Turan, Ö. (2003). Geçmişten Günümüze Bulgaristan Türkleri. Editör. Türbedar. E. Balkan Türkleri Balkanlarda Türk Varlığı. ASAM Yayınları. Ankara.

Türkdoğan, O. (1999). Etnik Sosyoloji: Türk Etnik Sosyolojisi. Timaş Yayınları.

Velikov, S. (1966). Kemaliskata Revolüsiya i Brlgarskata Obstestvenost (1918-1922). İzdatelstvo Na B1lgarskata Akademiya Na Naukite. Sofya.

Yenisoy, H. (1997). Bulgaristan Türklerinin Eğitim ve Kültür Tarihinden Sayfalar. Yeni Türkiye. Y1l no. 3. Sayı no. 16, Ankara. 